\title{
Sea-surface salinity variations in the northern Caribbean Sea across the Mid-Pleistocene Transition
}

\author{
S. Sepulcre, L. Vidal, K. Tachikawa, F. Rostek, and E. Bard \\ CEREGE, Université Aix-Marseille, CNRS, Collège de France, IRD, Europôle de l'Arbois, BP80, 13545 Aix-en-Provence, \\ France
}

Received: 4 June 2010 - Published in Clim. Past Discuss.: 29 June 2010

Revised: 7 January 2011 - Accepted: 12 January 2011 - Published: 11 February 2011

\begin{abstract}
By reconstructing past hydrologic variations in the Northern Caribbean Sea and their influence on the stability of the Atlantic Meridional Overturning Circulation (AMOC) during the last $940 \mathrm{ka}$, we seek to document climate changes in this tropical area in response to the Mid-Pleistocene Transition (MPT). Using core MD03-2628, we estimated past changes in sea surface salinity (SSS) using $\Delta \delta^{18} \mathrm{O}$, the difference between the modern, and the past $\delta^{18} \mathrm{O}$ of seawater (obtained by combining alkenone thermometer data with the $\delta^{18} \mathrm{O}$ of the planktonic foraminifera Globigerinoides ruber (white) and corrected for ice-sheet volume effects). Today, the lowest SSS values in the area studied are associated with the northernmost location of the Inter-Tropical Convergence Zone (ITCZ). The $\Delta \delta^{18} \mathrm{O}$ record obtained from core MD032628 exhibits glacial/interglacial cyclicity with higher values during all glacial periods spanning the last $940 \mathrm{ka}$, indicating increased SSS. A long-term trend was also observed in the $\Delta \delta^{18} \mathrm{O}$ values that exhibited a shift toward lower values for interglacial periods during the last $450 \mathrm{ka}$, as compared to interglacial stages older than $650 \mathrm{ka}$. A rise in SSS during glacial stages may be related to the southernmost location of the ITCZ, which is induced by a steeper cross-equator temperature gradient and associated with reduced northward cross-equatorial oceanic transport. Therefore, the results suggest a permanent link between the tropical salinity budget and the AMOC during the last $940 \mathrm{ka}$. Following the MPT, lower salinities during the last five interglacial stages indicated a northernmost ITCZ location that was forced by changes in the cross-equator temperature gradient and that was associated with the poleward position of
\end{abstract}

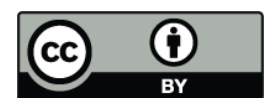

Correspondence to: S. Sepulcre (sepulcre@cerege.fr)
Southern Oceanic Fronts that amplify the transport of heat and moisture to the North Atlantic. These processes may have contributed to the amplification of the climate cycles that followed the MPT.

\section{Introduction}

The Mid-Pleistocene Transition (MPT) corresponds to a period of pronounced change within the climate system that varies between $1.5 \mathrm{Ma}$ to $650 \mathrm{ka}$ depending upon the paleoclimatic archive utilized (e.g., Head and Gibbard, 2005). The MPT led to the emergence of low-frequency, quasi-periodic climate cycles of asymmetrical shape and 100-ka in length, especially well-defined for the last 450 ka following a transitional interval (Tzedakis et al., 2009; Yin and Berger, 2010). In the absence of a marked change in insolation forcing (e.g., Maslin and Ridgwell, 2005), several hypotheses have been explored in order to explain this transition and include longterm changes in the atmospheric $\mathrm{CO}_{2}$ (Clark et al., 2006), changes in ice-sheet bedrock - the so-called "regolith hypothesis" (Clark and Pollard, 1998), or changes in ice-sheets dynamics (e.g., Berger et al., 1999; Tziperman and Gildor, 2003; Bintanja and van de Wal, 2008) leading to the progressive synchronization of the Northern Hemisphere and Antarctic ice-sheets (Raymo et al., 2006). The latter hypothesis implies a series of internal feedbacks, including changes in the deep-water circulation (McClymont et al., 2008) or the oceanic carbon pool (Raymo et al., 1990 and 1997; Mix et al., 1995; Schmieder et al., 2000; Hoogakker et al., 2006). Other studies have invoked the role of the tropics (McClymont and Rosell-Melé, 2005; Liu et al., 2008) or the Southern Hemisphere (Raymo et al., 2006; Schulz and Zeebe, 2006; Köhler

Published by Copernicus Publications on behalf of the European Geosciences Union. 
and Bintanja, 2008). However, no theory has supplanted another and no real consensus has been adopted to explain the causes for the MPT (e.g., Raymo and Huybers, 2008). In particular, the relationships between low and high latitudes during this time period remain unexplored (Rutherford and D'Hondt, 2000).

The tropical Atlantic is a key area for the modern climate system due to its role in the stability of the Atlantic Meridional Overturning Circulation (AMOC) which transports warm and salty waters from low latitudes into the North Atlantic. The efficiency of the AMOC may have a major impact on global climate change, particularly in northern Atlantic areas as suggested by model experiments and paleoclimatic data (e.g., Rahmstorf, 2002). Specifically, model simulations suggest that the strength of the AMOC is more sensitive to changes in the Atlantic salt budget than to variations in sea-surface temperature (SST) and, therefore, point to the importance of reconstructing past changes in low latitude hydrologic cycles (Rahmstorf et al., 2005; Rahmstorf, 2006). Under modern conditions, the Atlantic salt budget is determined by a combination of local and regional processes partly linked to tropical climate dynamics, such as the following:

1. The seasonal migration of the inter tropical convergence zone (ITCZ) which impacts the local salt budget in the tropical Atlantic through direct freshwater inputs via precipitation, as well as by the amount of freshwater exported toward the Pacific (Broecker et al., 1990; Zaucker and Broecker, 1992).

2. The duration and amplitude of the northward shift of the ITCZ. The northern ITCZ location is associated with the enhanced cross-equatorial transport of salt and heat into the North Atlantic (e.g., Dahl et al., 2005). The effect of ITCZ migration is clearly observed for meridional heat transport in the oceans, showing interhemispheric asymmetrical behavior for the Atlantic basin (Trenberth and Caron, 2001).

3. Remote control of the salt amount exported from the Indian Ocean to the tropical Atlantic via the South Atlantic through the "Agulhas leakage" (AL) under modern and past conditions (Gordon, 1996; Peeters et al., 2004; Biastoch et al., 2008). The relationships between tropical Atlantic hydrology, the AMOC, and climate changes have been determined through estimations of the salt budget at low latitudes during rapid climate change (Rühlemann et al., 1999; Schmidt et al., 2004), during glacial/interglacial climate transitions (Dürkoop et al., 1997), and on long time scales (Haug and Tiedemann, 1998; Haug et al., 2001), as well as through modelling studies (Wan et al., 2010).

In this study, we examined climate changes associated with the MPT in the tropics by estimating past variations in hy- drologic conditions in the northern Caribbean Sea and related changes in the AMOC. Here, we discuss the variations of past sea-surface salinity (SSS) related to the ITCZ location, and estimate past SSS at the core site using the $\delta^{18} \mathrm{O}$ of seawater, by combining oxygen isotopic measurements obtained from the surface-dwelling planktonic foraminifer Globigerinoides ruber (white) and using SSTs obtained from the alkenone unsaturation index $\left(\mathrm{U}_{37}^{K^{\prime}}\right)$ analysis. We corrected the $\delta^{18} \mathrm{O}$ of seawater for ice-sheet volume effects and calculated the $\Delta \delta^{18} \mathrm{O}$ as the difference between the modern and past $\delta^{18} \mathrm{O}$ for seawater. Major trends observed in the $\Delta \delta^{18} \mathrm{O}$ record were that a marked glacial/interglacial pattern spanned the entire record and that a shift toward decreased SSS's during interglacials occurred for the last $450 \mathrm{ka}$ as compared to the previous time interval $(650-940 \mathrm{ka})$. On the glacial/interglacial timescale, the core MD03-2628 results emphasize the existing link between the ITCZ and the AMOC for the past $940 \mathrm{ka}$. The results obtained for interglacial stages for the last $450 \mathrm{ka}$ allowed us to discuss the causes and consequences of ITCZ migration following the MPT, as well as the possible relationships between changes in oceanic and atmospheric northward heat transfer associated with ITCZ migration.

\section{Modern climate and hydrologic parameters}

Core MD03-2628 was retrieved in the Walton Basin $(26.56 \mathrm{~m}$ of length, $17^{\circ} 21.26^{\prime} \mathrm{N}, 77^{\circ} 42.45^{\prime} \mathrm{W}, 846 \mathrm{~m}$ water depth, Fig. 1) during the IMAGES MD132 expedition, aboard R.V. Marion Dufresne in 2003. All of the details regarding the core's sedimentology are given in the auxiliary material of Sepulcre et al. (2009). The Walton Basin is located in the northeastern portion of the Nicaragua Rise, which separates the Colombian Basin from the Cayman Basin (Fig. 1a). The Walton Basin consists of a deep seaway between the Jamaican shelf and the Pedro Bank, with water depths ranging between 200 and $2000 \mathrm{~m}$ (Fig. 1b). Modern climate and oceanographic data near the core MD03-2628 location (Fig. 1b) were extracted from the DASILVA dataset (precipitation and evaporation rates were obtained at $17.5^{\circ} \mathrm{N}$, $77.5^{\circ} \mathrm{W}$, da Silva et al., 1994), the NOAA data center (atmospheric temperature at Montego Bay, $18.47^{\circ} \mathrm{N}, 77.99^{\circ} \mathrm{W}$, Jamaica), and the LEVITUS (1994) dataset (at $17.5^{\circ} \mathrm{N}$, $\left.77.5^{\circ} \mathrm{W}\right)$.

\subsection{Climatology and hydrologic parameters}

The climate in the Caribbean Sea is typically tropical without a pronounced cooling season (Fig. 2a). A maximum easterly zonal wind at $925 \mathrm{hPa}$ in the Caribbean region is called the Caribbean Low-Level Jet (CLLJ). The CLLJ is at its maximum in winter (Fig. 1a), when the atmospheric temperature gradient between the Caribbean zone and the Tropical North Atlantic is large and the ITCZ is further south (Wang and Lee, 2007). The summer wet period extends from 


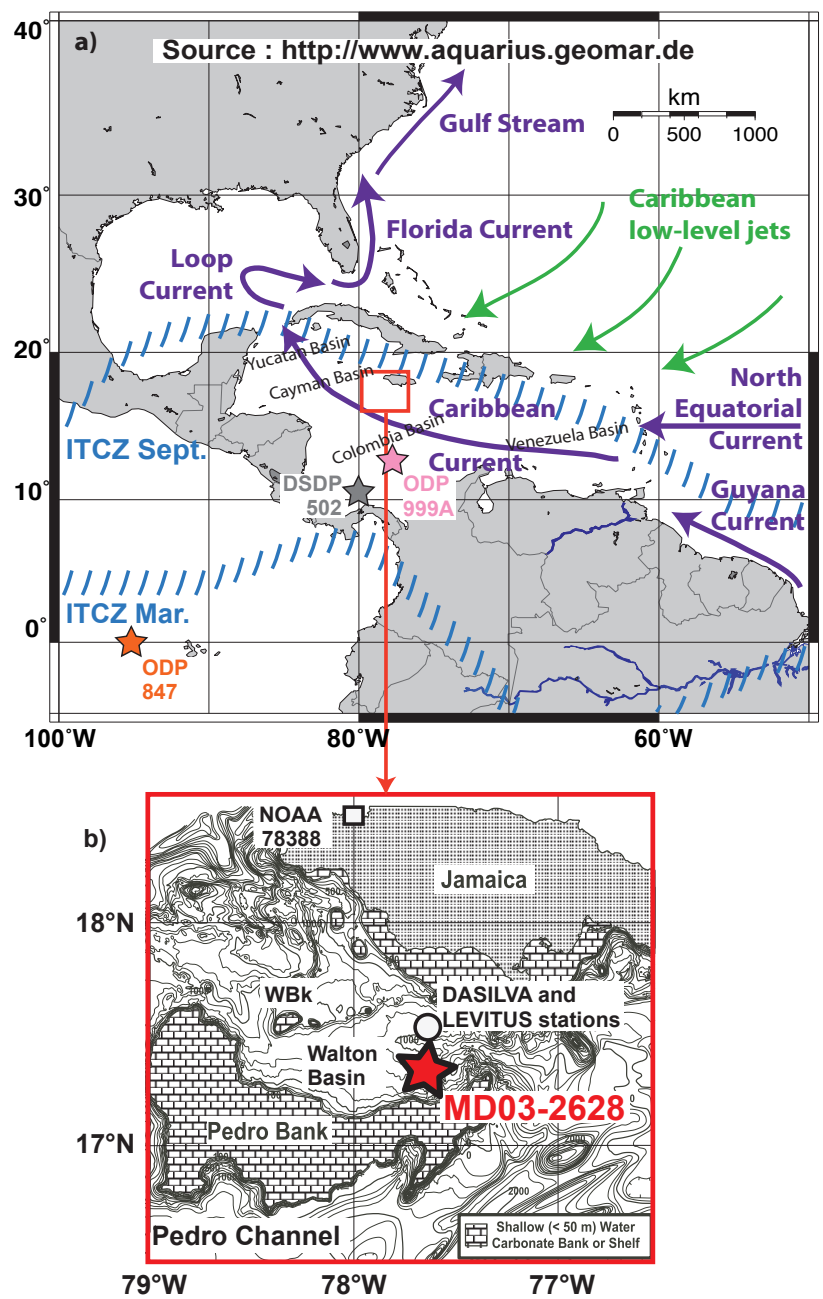

Fig. 1. The modern setting of the studied zone and the location of core MD03-2628. (a) The climatic and oceanic context of the Caribbean Sea; the purple arrows represent surface currents; the green arrows represent winds; and the blue hatched zones represent the seasonal extreme positions of the Inter-Tropical Convergence Zone (ITCZ, e.g., Haug et al., 2003). The locations of cores ODP 999A $\left(12^{\circ} 45^{\prime} \mathrm{N}, 78^{\circ} 44^{\prime} \mathrm{W}, 2827 \mathrm{~m}\right.$ in water depth, pink star); DSDP $502\left(11^{\circ} \mathrm{N}, 80^{\circ} \mathrm{W}, 3051 \mathrm{~m}\right.$ in water depth, gray star $)$; and ODP $847\left(0^{\circ} \mathrm{N}, 95^{\circ} \mathrm{W}, 3373 \mathrm{~m}\right.$ in water depth, orange star $)$ are also specified. (b) A zoom-in of the Walton Basin and the location of core MD03-2628 (WBk: Walton Bank). The location for the LEVITUS (1994) and the DASILVA (da Silva et al., 1994) stations at $17.5^{\circ} \mathrm{N}, 77.5^{\circ} \mathrm{W}$; and for the NOAA (station 78388) station $\left(18.47^{\circ} \mathrm{N}, 77.99^{\circ} \mathrm{W}\right)$ are also specified in Fig. $1 \mathrm{~b}$ (adapted from Reijmer and Andresen, 2007).

May to November and can be divided in two time intervals (Fig. 2b, Taylor et al., 2002). From May to July, precipitation reaches $90 \mathrm{~mm} \mathrm{month}^{-1}$ and from August to November, during the hurricane season, values increase to $130 \mathrm{~mm} \mathrm{month}^{-1}$ as a result of ITCZ positioning (Figs. 1a, 2b, and 3c; see Sect. 2.2 for details). Evaporation rates (Fig. 2c) exhibit small seasonal variations, with maximum values occurring

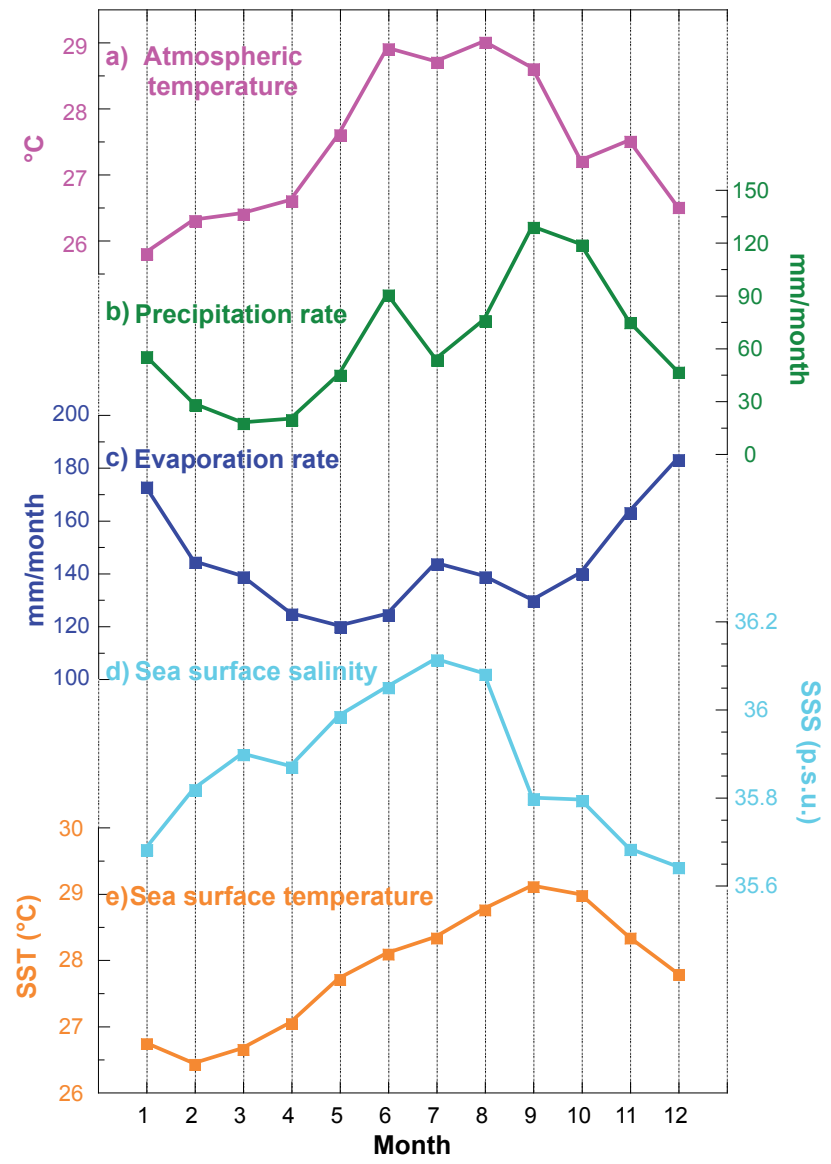

Fig. 2. Monthly climate and sea-surface water parameters. (a) Atmospheric temperature from NOAA climate station 78388; (b) precipitation; (c) evaporation rates from the DASILVA dataset (da Silva et al., 1994); (d) Sea-surface salinity (SSS); and (e) temperature (SST) from the LEVITUS (1994) dataset.

during winter (183 $\mathrm{mm} \mathrm{month}^{-1}$ in December) and minimal values occurring during spring (120 mm month ${ }^{-1}$ in May). Seasonal changes may be related to the strength of the CLLJ (see above).

Near the core MD03-2628 location, hydrographic conditions indicate that SST-monthly variations are limited, within a range of 26.5 to $29^{\circ} \mathrm{C}$, with a trend of high and low values during boreal summer and winter, respectively (Fig. 2e). Monthly surface water salinity (SSS) ranges between 35.6 and 36.1 p.s.u. (Fig. 2d) and is mainly controlled by seasonal ITCZ migration and freshwater advection (see Sect. 2.2 for details) (Fig. 1a). SSS minimum values are linked to the northern location of the ITCZ at the studied site in September, and from October to December to a "late" contribution of the freshwater supply from the Orinoco River (see below). SSS maximum values are reported in July. No clear relationship appears to exist between the evaporation rate and SSS at the core MD03-2628 location (Fig. 2c and d). 

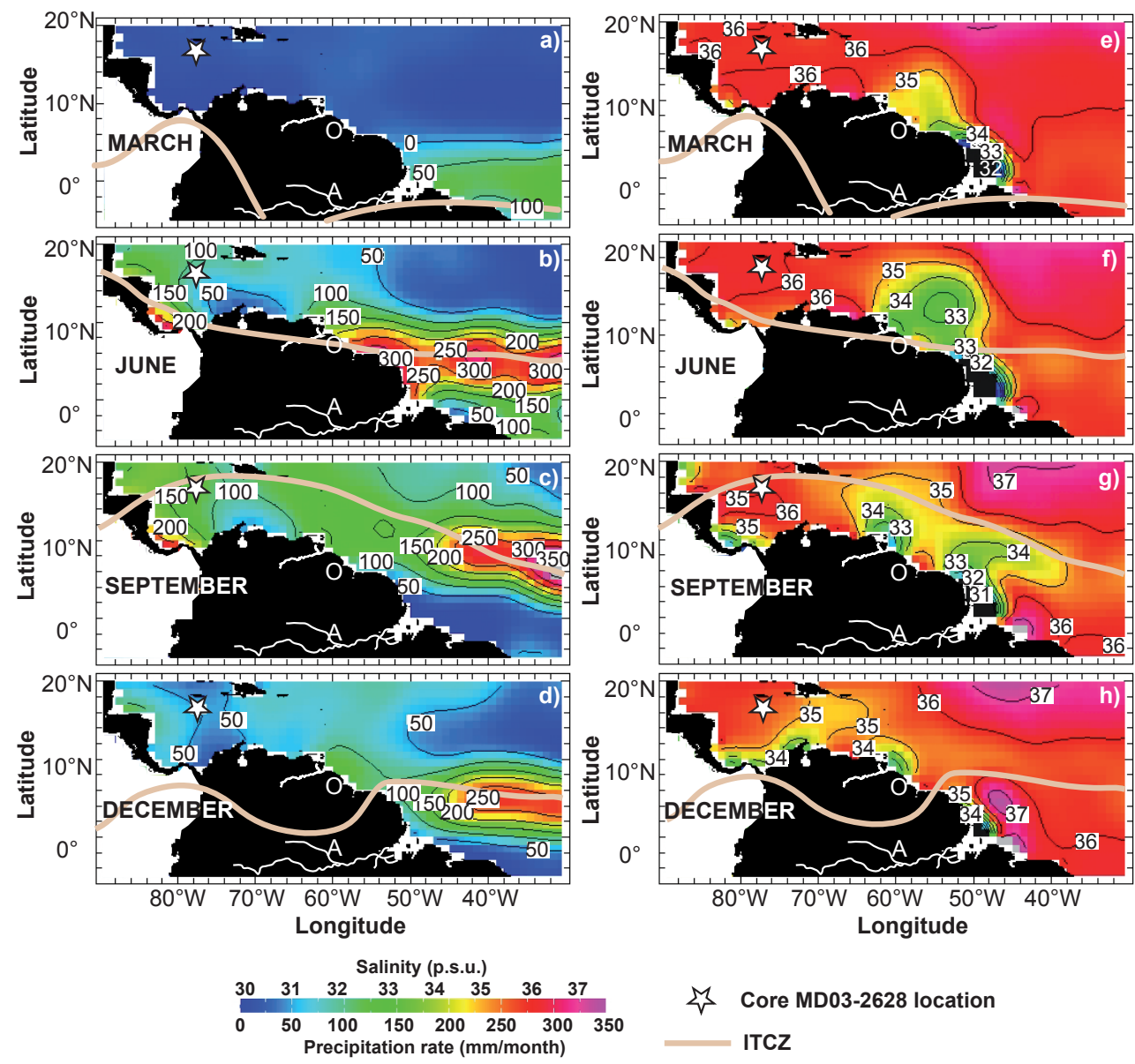

is Core MD03-2628 location ITCZ

Fig. 3. Maps of precipitation rates (a-d) and sea surface salinities (e-h) during March (a and e), June (b and $\mathbf{f})$, September (c and $\mathbf{g}$ ), and December ( $\mathbf{d}$ and $\mathbf{h}$ ). The core MD03-2628 location is shown by a star, and the ITCZ position is shown by the thick beige line (e.g., Haug et al., 2003). The Orinoco and Amazon Rivers are indicated by the $\mathrm{O}$ and A letters, respectively. Maps were constructed from http://ingrid.ldeo.columbia.edu/ using the DASILVA (da Silva et al., 1994) and LEVITUS (1994) datasets.

\subsection{Salinity variability and surface-water circulation}

Caribbean Surface Water $(0-50 \mathrm{~m})$ flows from the southeast toward the northwest within the Caribbean Current (Fig. 1a) (Wüst, 1964; Tomczak and Godfrey, 2003), and results from the mixing of South Atlantic Water from the Guyana Current and Equatorial water from the North Equatorial Current (Fig. 1a) (Schmitz and Richardson, 1991).

Seasonal SSS variations are determined by the position of the ITCZ through both direct inputs of freshwater from local precipitation and by the advection of low SSS water from surface currents. In March, the ITCZ is located southwards and provides freshwater to the Amazon Basin (Fig. 3a). The freshwater supply to the studied area is limited and SSS values are 35.9 p.s.u. (Figs. $2 \mathrm{~d}$ and 3e). In June, the ITCZ is located further north above the Orinoco Basin (Fig. 3b). During that time, the maximum discharge of the Amazon River is observed (Fig. 3f, Morrisson and Nowlin, 1982; Müller-Karger et al., 1988; Hernandez-Guerra and Joyce,
2000; Hellweger and Gordon, 2002; Chérubin and Richardson, 2007). However, the low SSS waters that are transported northward through the Guyana Current do not reach the northern Caribbean Sea (Figs. 2d, 3f and g). As a result, the SSS value at the site location is high (36.1 p.s.u., Figs. $2 \mathrm{~d}$ and $3 \mathrm{f}$ ). The northward migration of the ITCZ in September results in high precipitation rates within the studied area (Figs. 2b and 3c) and SSS values decrease to 35.8 p.s.u. (Figs. $2 \mathrm{~d}$ and $3 \mathrm{~g}$ ). Freshwaters originating from the Orinoco River flow westward into the Caribbean Sea (Fig. 3g, Chérubin and Richardson, 2007). In December, the ITCZ moves southward (Fig. 3d) and Orinoco freshwaters reach the study area causing a decrease in SSS to a level of 35.7 p.s.u. (Chérubin and Richardson, 2007) (Figs. 2d and 3h).

Under modern conditions, SSS seasonal variability at the core site is best explained by the northward position of the ITCZ during boreal summer as a result of in situ freshwater input by precipitation during September and the "delayed" 
advection of low SSS waters during late summer (September to November) from the Orinocco River, for which freshwater supply occurs in June. Therefore, in the following, we associate low SSS values with the northern location of the ITCZ.

\subsection{Oceanic intermediate and deep-water circulation}

Below surface waters, Subtropical UnderWater (SUW) lies between 50 and $300 \mathrm{~m}$ in the Walton Basin (Fig. S1). The SUW water mass originates in the Sargasso Sea and is characterized by a salinity maximum of 36.7 p.s.u. (Morrison and Nowlin, 1982). At the studied site, Antarctic Intermediate Water (AAIW) is found at intermediate water depths (300-1000 m) and is mixed with underlying North Atlantic Deep Water (NADW) (Wüst, 1964; Fratantoni et al., 1997; Tomczak and Godfrey, 2003). Between 900 and $1900 \mathrm{~m}$, the Caribbean Sea is filled with upper NADW mixed with AAIW, as well as with Upper Circumpolar Deep Water that has a salinity of approximately 35 p.s.u. (Wüst, 1964; Fratantoni et al., 1997; Johns et al., 2002 in Schmidt et al., 2006a; Tomczak and Godfrey, 2003).

\subsection{Globigerinoides ruber and coccolithophorid distribution within the water column}

Even if the Caribbean Sea is an oligotrophic area, its primary productivity $(\mathrm{PP})$ shows seasonal variability. Maximum PP occurs between February and April when nutrients are carried to the northern Caribbean Sea either from upwelling activity that is created by the CLLJ (Müller-Karger et al., 1988; Hu et al., 2004) in the Southern portion of the Caribbean Sea, or by river plumes that are carried by the Guyana Current (Martinez et al., 2007 and references therein).

The planktonic foraminifer species G. ruber inhabits the upper portion of the water column, between 0 and $20 \mathrm{~m}$ (Schmuker and Schiebel, 2002, Fig. S1), with corresponding temperature and salinity averaged values of $27^{\circ} \mathrm{C}$ and 35.9 p.s.u., respectively (February to April period, Fig. $2 \mathrm{~d}$ and e).

Coccolithophorids that produce $\mathrm{C}_{37}$ alkenone molecules occupy the entire photic zone of the Caribbean Sea, corresponding roughly to the depth of the nutricline (Kameo et al., 2004, Fig. S1). In the Northern Caribbean Sea, the nutricline fits within the limit of surface waters and the SUW (i.e. the first $50 \mathrm{~m}$ of the water column, Fig. S1).

Under modern conditions, coccolithophorids (Kameo et al., 2004) and G. ruber (Schmuker and Schiebel, 2002) both dwell in nearly the same depth range within the water column of the Caribbean Sea. Today, the seasonality signal is small in SST for the Northern Caribbean Sea (Sect. 2.1 and Fig. 2). The thermocline is not well-defined, with nearly constant temperature values of approximately $27^{\circ} \mathrm{C}$ down to $50 \mathrm{~m}$ in water depth, followed by a progressive decrease to reach $15^{\circ} \mathrm{C}$ at $400 \mathrm{~m}$ (Fig. S1). Therefore, in the following we consider that coccolithophorids and G. ruber inhabit almost identical temperature conditions (Fig. S1).

\section{Methods}

Core MD03-2628 was sampled at every $20 \mathrm{~cm}$ interval for the $\delta^{18} \mathrm{O}$ analysis and for the $\mathrm{U}_{37}^{K^{\prime}}$ determination. Samples for $\delta^{18} \mathrm{O}$ measurements were wet-sieved for the $<63 \mu \mathrm{m}, 63$ $150 \mu \mathrm{m}$, and $>150 \mu \mathrm{m}$ fractions and dried in an oven at $50^{\circ} \mathrm{C}$. G. ruber $(250-355 \mu \mathrm{m})$ was hand-picked from the $>150 \mu \mathrm{m}$ fraction. Samples for the alkenone analysis were freeze-dried and ground in a mortar. All of the preparations and instrumental measurements were carried out at CEREGE.

$\delta^{18} \mathrm{O}$ measurements were performed on five to ten individuals of G. ruber using a Finnigan Delta Advantage mass spectrometer directly coupled to an automatic carbonate preparation device (Kiel Device III), dedicated to the analysis of small samples providing low gas amounts and calibrated to the international scale (Vienna Pee Dee Belemnite VPDB). Analytical precision of the method was controlled with the regular standard analyses of NBS19 and was better than $0.04 \%$ of $\delta^{18} \mathrm{O}_{\mathrm{VPDB}}(1 \sigma ; n=169)$. The reproducibility of this approach was tested using replicate measurements of G. ruber from the same level at different depths in the core, and showed no significant shift (Table S1).

The analytical procedure and the extraction method for the $\mathrm{C}_{37}$ alkenone measurements are fully described in Sonzogni et al. (1997). The quality of the measurements carried out at CEREGE was confirmed by an international intercalibration study (Rosell-Melé et al., 2001). The analytical accuracy was approximately $0.01(1 \sigma)$. SSTs were calculated with the $\mathrm{U}_{37}^{K^{\prime}}$ index using the calibrations of Sonzogni et al. (1997) and Conte et al. (2006). The global calibration provided by Conte et al. (2006) sought to take into account the full range of temperatures by using a polynomial approach, with an uncertainty of $\pm 0.6^{\circ} \mathrm{C}$. Indeed, there is a decrease in the sensitivity of the $\mathrm{U}_{37}^{K^{\prime}}$ proxy at temperatures above $24^{\circ} \mathrm{C}$. The work of Sonzogni et al. (1997) was specifically performed for temperatures higher than $24^{\circ} \mathrm{C}$. Sonzogni et al. (1997) provided a detailed analysis for higher temperatures, with a linear relationship between the $\mathrm{U}_{37}^{K^{\prime}}$ proxy and temperatures, and an uncertainty of $\pm 0.7^{\circ} \mathrm{C}$. SST records from both calculations are presented and discussed below (Sect. 4.2. and Fig. 4b).

\section{Results}

\subsection{Stable isotope record}

Chronology in core MD03-2628 is based upon the G. ruber $\delta^{18} \mathrm{O}$ record (Fig. 4a) as well as paleomagnetic measurements and has been fully described elsewhere (see auxiliary material in Sepulcre et al., 2009 for details). Briefly, the age model was obtained using a correlation for the $\delta^{18} \mathrm{O}$ 


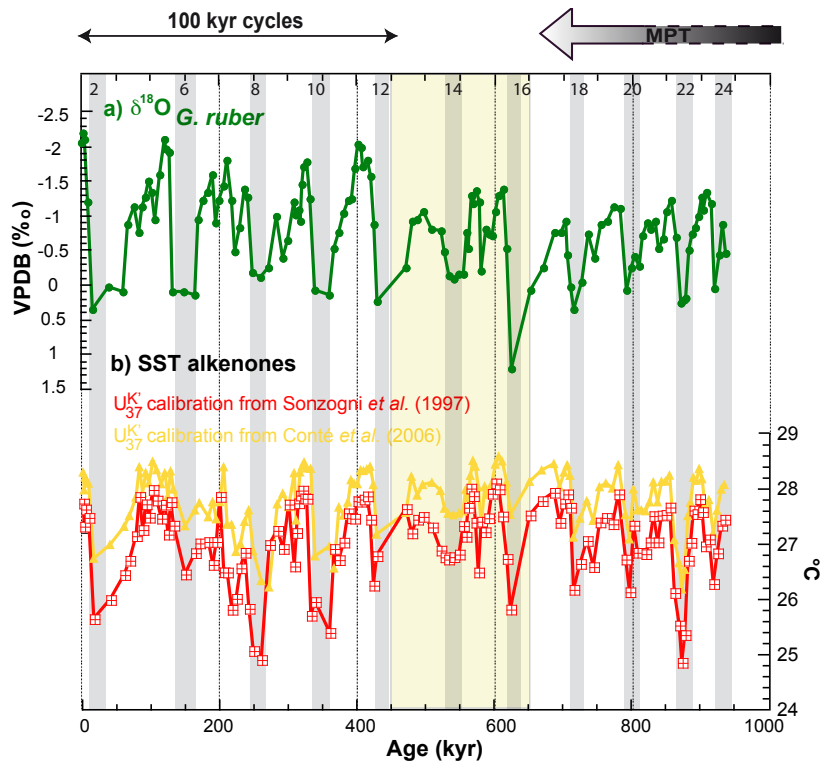

Fig. 4. Core MD03-2628 records for: (a) the $\delta^{18} \mathrm{O}$ of the planktonic foraminifera Globigerinoides ruber (green curve and dots); and (b) sea-surface temperatures as determined by the $\mathrm{U}_{37}^{K^{\prime}}$ index and calculated with the Sonzogni et al. (1997) (red curve and squares) and Conte et al. (2006) (yellow curve and triangles) calibrations. Light gray bars and even numbers show the glacial stages as defined by $\delta^{18} \mathrm{O}$. The yellow area indicates the 650 to $450 \mathrm{ka}$ time interval, when the duration and shape of the climate cycles changed (see text for details).

record with a reference record (Lisiecki and Raymo, 2005) using the software "Analyseries" (Paillard et al., 1996). The isotopic correlation was supported by the identification of the paleomagnetic events in core MD03-2628, such as the Delta ( $\sim 685 \mathrm{ka})$, the Kamikatsura ( $900 \mathrm{ka})$, the Santa Rosa ( $\sim 940 \mathrm{ka})$, and the Bruhnes-Matuyama reversal ( 780 ka). The core MD03-2628 record spans the last $940 \mathrm{ka}$, up to MIS 24 (Fig. 4a). The average sedimentation rates for interglacial and glacial periods were 4 and $2 \mathrm{~cm} \mathrm{ka}^{-1}$, respectively, with a corresponding time-resolution of 5 and $10 \mathrm{ka}$.

To test the isotopic stratigraphy established with the $\delta^{18} \mathrm{O}$ of G. ruber, the $\delta^{18} \mathrm{O}$ of the benthic foraminifera Cibicidoides wuellerstorfi $(250-355 \mu \mathrm{m})$ was measured on core MD03-2628 for the last five glacial-interglacial Terminations in order to evaluate the synchronicity between both $\delta^{18} \mathrm{O}$ records over glacial-interglacial changes (data not shown). The records are in good agreement, indicating that the correlation procedure would have been the same when using the benthic $\delta^{18} \mathrm{O}$ record of core MD03-2628, and then reinforcing the original chronological framework established for core MD03-2628 at the studied temporal resolution.

A relative uncertainty was estimated for the core MD032628 age model by comparing the original age model from Sepulcre et al. (2009) to two other chronologies based on the stacking for the MD03-2628 $\delta^{18} \mathrm{O}$ of G. ruber to the following: (1) the composite $\delta^{18} \mathrm{O}$ record of Asian stalagmites dated using Uranium-Thorium measurements compiled by Cheng et al. (2009) for the last $350 \mathrm{ka}$ (Fig. S2a), and (2) the Antarctic $\mathrm{CO}_{2}$ record with the Kawamura et al. (2007) chronology based on the $\mathrm{O}_{2} / \mathrm{N}_{2}$ ratio for the last $360 \mathrm{ka}$ (Fig. S2b). Mean age differences of $-2.4 \mathrm{ka}$ (std. dev. $=2.5$, $n=33$ ) and $2.3 \mathrm{ka}$ (std. dev. $=6.9, n=19)$ were obtained between the published age model (Sepulcre et al., 2009) and the new chronology based on the Cheng et al. (2009) stalagmite $\delta^{18} \mathrm{O}$ record for interglacial and glacial stages, respectively. Calculations obtained using an age model based on the Kawamura et al. (2007) record yielded average differences of $-1.3 \mathrm{ka}$ (std. dev. $=3.6, n=33$ ) during interglacials, and of $0.01 \mathrm{ka}$ (std. dev. $=4.2, n=19$ ) during glacials. Therefore, the differences between the three chronologies are minor compared to the temporal resolution of our study (Fig. S3). Taken together, as a conservative estimate, we chose a mean relative error for the age model of core MD03-2628 of approximately $\pm 2.5 \mathrm{ka}$.

The $\delta^{18} \mathrm{O}$ values of $G$. ruber ranged from $-2.2 \%$ o (Holocene) to $1.2 \%$ (MIS 16) (Fig. 4a). The results are in good agreement with previous planktonic $\delta^{18} \mathrm{O}$ records from the Caribbean Sea spanning the last $350 \mathrm{ka}$ (Wolff et al., 1998; Schmidt et al., 2004 and 2006a). With the exception of MIS 16 , the $\delta^{18} \mathrm{O}$ values for glacials are nearly constant at approximately $0-0.4 \%$ ofor the overall record. From 940 to $650 \mathrm{ka}$, glacial-interglacial amplitudes for the $\delta^{18} \mathrm{O}$ variations through glacial Terminations were approximately $1 \%$, with values for interglacials ranging between -1.4 and $-0.7 \%$ (Fig. 4a). Between 650 and $450 \mathrm{ka}$ (from MIS 16 to MIS 13), we observed a very high value for MIS 16 , out of range for other glacial $\delta^{18} \mathrm{O}$ values recorded, and a $\delta^{18} \mathrm{O}$ value for MIS 14 as high as a cold event during MIS 15 (Fig. 4a). Glacial-interglacial amplitudes spanning Terminations from $450 \mathrm{ka}$ to the core top increased to approximately $2 \%$, as compared to the oldest time interval. The change in amplitude is due to a shift in interglacial stage values toward lower $\delta^{18} \mathrm{O}$, ranging from -2.2 to $-1.4 \%$ (Fig. 4a). In the following, we define three time intervals corresponding to downcore variations in the $\delta^{18} \mathrm{O}$ of $G$. ruber, as follows: (1) the period older than $650 \mathrm{ka}$, (2) the $650-450 \mathrm{ka}$ timeinterval, and (3) the last $450 \mathrm{ka}$.

The core top value for the $\delta^{18} \mathrm{O}$ of $G$. ruber was $-2 \%$, very close to the expected value $(-2.3 \%$ o $)$ obtained when using the equation of Mulitza et al. (2003) and modern hydrologic data (the $\delta^{18} \mathrm{O}_{\text {seawater }}=1.01 \%$ o from the Global Seawater $\delta^{18} \mathrm{O}$ Database (Schmidt et al., 1999) and the mean annual $\mathrm{SST}=27.8^{\circ} \mathrm{C}$ at the core location). The Mulitza et al. (2003) equation provided a result that is in better agreement with measured $\delta^{18} \mathrm{O}$ than the Bemis et al. (1998) equation. The core top $\delta^{18} \mathrm{O}$ value was close to the calculated value even when we considered the possible shifts between modern and fossil G. ruber from Holocene samples (Waelbroeck et al., 2005). In the following, we used the equation of Mulitza et al. (2003) to calculate the $\delta^{18} \mathrm{O}$ record of seawater. 


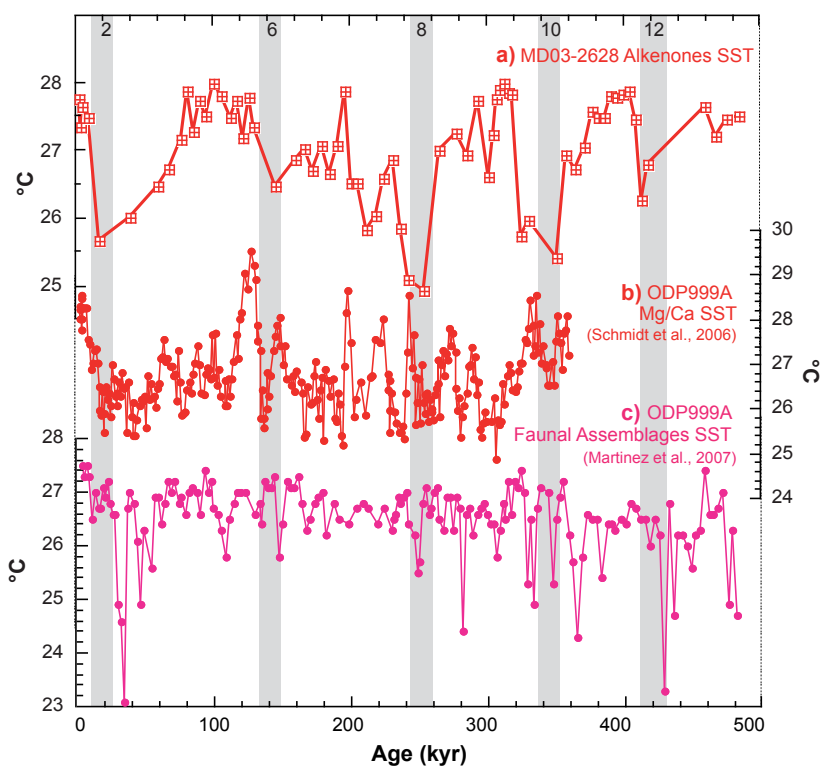

Fig. 5. A comparison of the MD03-2628 sea-surface temperature (SST) record with other SST reconstructions in the Caribbean Sea. (a) A zoom-in for the last $500 \mathrm{ka}$ for the SST results obtained using the $\mathrm{U}_{37}^{K^{\prime}}$ index on core MD03-2628; (b) and (c) results obtained on ODP core 999A (Fig. 1a) by (b) Schmidt et al. (2004 and 2006a), with $\mathrm{Mg} / \mathrm{Ca}$ SST results (red curve and dots) and by (c) Martinez et al. (2007), with mean annual values of faunal SST reconstructions (pink curve and dots). Light gray bars and even numbers are the same as in Fig. 4.

\subsection{Paleosea-surface temperatures}

The SST records of core MD03-2628 calculated using the Sonzogni et al. (1997) and Conte et al. (2006) calibrations both exhibited a well-defined glacial-interglacial cyclicity, with lower values during glacials (Fig. 4b). No long term trend was observed for both SST records.

With the Sonzogni et al. (1997) calibration, the core top SST was $27.7^{\circ} \mathrm{C}$, in good agreement with modern annual SST (Fig. 2e). SST values ranged from a minimum value of $24.8^{\circ} \mathrm{C}$ (MIS 22) to a maximum value of $28.1^{\circ} \mathrm{C}$ (MIS 15). Interglacial and glacial stages had an average SST of $27.3^{\circ} \mathrm{C}\left( \pm 0.07^{\circ} \mathrm{C}, 1 \sigma_{m}\right.$ with $\left.\sigma_{m}=\frac{\sigma}{\sqrt{n}}, n=69\right)$ and $26.5^{\circ} \mathrm{C}$ $\left( \pm 0.14^{\circ} \mathrm{C}, 1 \sigma_{m}, n=33\right)$, respectively. The average amplitude of the glacial-interglacial change was approximately $1.9^{\circ} \mathrm{C}\left( \pm 0.17^{\circ} \mathrm{C}, 1 \sigma_{m}, n=11\right)$, with values ranging from $0.78^{\circ} \mathrm{C}$ to $2.8^{\circ} \mathrm{C}$ (Terminations VI and $\mathrm{X}$, respectively).

By using the calibration of Conte et al. (2006), we obtained SST values ranging from $26.2^{\circ} \mathrm{C}$ during MIS 8 and MIS 22, and $28.6^{\circ} \mathrm{C}$ during MIS 15 . The SST at the core top was $28.3^{\circ} \mathrm{C}$, which is slightly higher than the annual modern SST value of $27.8^{\circ} \mathrm{C}$ (Fig. 2e). The average interglacial and glacial SST values were $28^{\circ} \mathrm{C}\left( \pm 0.04^{\circ} \mathrm{C}, 1 \sigma_{m}, n=69\right)$ and $27.3{ }^{\circ} \mathrm{C}\left( \pm 0.1{ }^{\circ} \mathrm{C}, 1 \sigma_{m}, n=33\right)$, respectively. SST variations during the Terminations ranged from 0.3 to $2.1^{\circ} \mathrm{C}$ for
Terminations $\mathrm{V}$ and $\mathrm{X}$, respectively, with an average value of $1.2^{\circ} \mathrm{C}\left( \pm 0.15^{\circ} \mathrm{C}, 1 \sigma_{m}, n=11\right)$.

The average SST values calculated using both calibration methods are in good agreement if we take into account the related uncertainties. The main difference relies on the amplitude of the SST change during the Terminations which is due to a higher sensitivity of the Sonzogni et al. (1997) calibration in a temperature range warmer than $24^{\circ} \mathrm{C}$, such as at the core MD03-2628 site, as compared to the calibration of Conte et al. (2006). Therefore, in the following, we use the SST reconstruction from the Sonzogni et al. (1997) calibration.

Since, here, we present the first alkenone-based SST reconstruction available for the Caribbean Sea, our data were compared with previous SST records from the same area obtained from micropaleontological assemblages (Hüls and Zahn, 2000; Schmidt et al., 2006a; Martinez et al., 2007), and foraminiferal $\mathrm{Mg} / \mathrm{Ca}$ (Hastings et al., 1998; Schmidt et al., 2004 and 2006a) (ODP core 999A, Figs. 1a and 5).

The SST difference through Termination I was welldocumented, showing a glacial to interglacial change ranging from 1 to $4{ }^{\circ} \mathrm{C}$ (Fig. $5 \mathrm{~b}$ and c). Thus, a value of approximately $2^{\circ} \mathrm{C}$, as determined in core MD03-2628 (Fig. 5a), is within the range of previous reconstitutions.

For the last $350 \mathrm{ka}$, all of the SST records exhibited a glacial/interglacial pattern with a similar amplitude for glacial Terminations except for the MIS 5e and Termination IV $\mathrm{Mg} / \mathrm{Ca}$-SSTs, and the MIS 3 micropaleontological-SSTs (Fig. 5).

When comparing $\mathrm{Mg} / \mathrm{Ca}$ and alkenone SST records, most of the differences were within the uncertainties of both paleothermometers $\left( \pm 0.4\right.$ and $\pm 0.7^{\circ} \mathrm{C}$, respectively). However, additional factors might imprint SST reconstructions as low sedimentation rates at the core MD03-2628 location that may have smoothed the SST signal and its amplitude as compared to the record of Schmidt et al. (2006a). For the 360-465 ka time-interval, differences between both reconstructions are related to the dissolution processes described at the core ODP 999A site by Schmidt et al. (2006a).

Alkenone and micropaleontological SST records are similar and within the uncertainties of both methods $( \pm 0.7$ and $\pm 0.5-1.5^{\circ} \mathrm{C}$, respectively), except for the time-interval older than $450 \mathrm{ka}$. According to Martinez et al. (2007), the average distance to the nearest analog tends to increase with time with maximum values reached during MIS 13-14. Therefore, SST reconstructions based upon micropaleontological assemblages can not be considered as fully robust before $450 \mathrm{ka}$.

Finally, part of the observed discrepancies may also be related to the different core sites, and in particular the nearly permanent location inside the Atlantic Warm Pool for core ODP 999A, unlike core MD03-2628 (for a complete discussion, see Ziegler et al., 2008). Additionally, SST records from core ODP 999A exhibited differences between reconstructions depending on the proxy utilized, whereas 
they were determined on the same marine archive (Schmidt et al., 2006a; Martinez et al., 2007). Therefore, even when taking into account the few differences between available SST reconstructions, general agreement was found between the alkenone-SST record in core MD03-2628 and other SST records, supporting the application of alkenone-SST for estimations of paleohydrological variability in the northern Caribbean Sea. The impact of these SST differences on the calculation of the $\delta^{18} \mathrm{O}$ of seawater is evaluated in Sect. 4.3.

\subsection{The calculation of local surface $\delta^{18} O$ variability}

By combining the $\delta^{18} \mathrm{O}$ of $G$. ruber and the alkenone-SST records of core MD03-2628, we estimated the $\delta^{18} \mathrm{O}$ of seawater at the core location (Fig. 6a). Since foraminifera and coccolithophorids have different ecologies, we first considered the potential impact of past changes in their growth depth and seasonality on the hydrological reconstruction. Under modern conditions, coccolithophorids and G. ruber inhabit nearly the same depth range within the water column (Fig. S1 and Sect. 2.4., Kameo et al., 2004; Schmuker and Schiebel, 2002). Reconstructions of the stratification between surface and subsurface waters in the Northern Caribbean Sea for the past $300 \mathrm{ka}$ have shown that coccolithophorid populations were controlled by the nutrient supply rather than the temperature influence, and that the studied groups are always occupied within the first $50 \mathrm{~m}$ of the water column (Kameo et al., 2004). G. ruber is a symbiont-bearing species, so its migration in the water column deeper than $50 \mathrm{~m}$ seems unlikely. The impact of past seasonality changes is difficult to estimate. At the core MD03-2628 site, we know from modern conditions that the seasonality signal in the SST record is weak (Fig. 2e). Additionally, low sedimentation rates may have contributed to smooth the record. Therefore, we assume that past changes in the growth depth and seasonality did not significantly bias the climatic record at the core MD03-2628 site at the studied temporal resolution.

Glacial-interglacial variability was well-expressed in the past $\delta^{18} \mathrm{O}$ of seawater, with values ranging from 1.05 to $4.12 \%$ and with a trend of higher $\delta^{18} \mathrm{O}$ during glacials. Glacial values were nearly constant for the 940-650 ka time interval when compared to the $450-0 \mathrm{ka}$ period, with values of $3.08 \pm 0.06 \%$ o $\left(1 \sigma_{m}, n=12\right)$ and $2.97 \pm 0.07 \%$ o $\left(1 \sigma_{m}\right.$, $n=15)$, respectively. Interglacial stages displayed the same pattern as the $\delta^{18} \mathrm{O}$ of $G$. ruber, with lower values of $0.61 \%$ o $\left( \pm 0.07,1 \sigma_{\text {sum }}\right.$, where $\left.\sigma_{\text {sum }}=\sqrt{\sigma_{1}^{2}+\sigma_{2}^{2}}\right)$ for the last $450 \mathrm{ka}$ $\left(1.7 \% \circ \pm 0.05,1 \sigma_{m}, n=37\right)$ as compared to the $940-650 \mathrm{ka}$ time interval $\left(2.3 \% \circ \pm 0.04,1 \sigma_{m}, n=24\right)$. Taking into account the uncertainty of the SST reconstruction $\left( \pm 0.7^{\circ} \mathrm{C}\right)$ led to an error of $0.23 \%$ for the calculation of the past $\delta^{18} \mathrm{O}$ of seawater, a value that is lower than the difference of $0.61 \%$ o observed for interglacial stages from 940-650 ka and from $450-0 \mathrm{ka}$, and the average glacial-interglacial amplitude of $1.46 \%$ o $\left( \pm 0.17,1 \sigma_{m}, n=11\right)$.

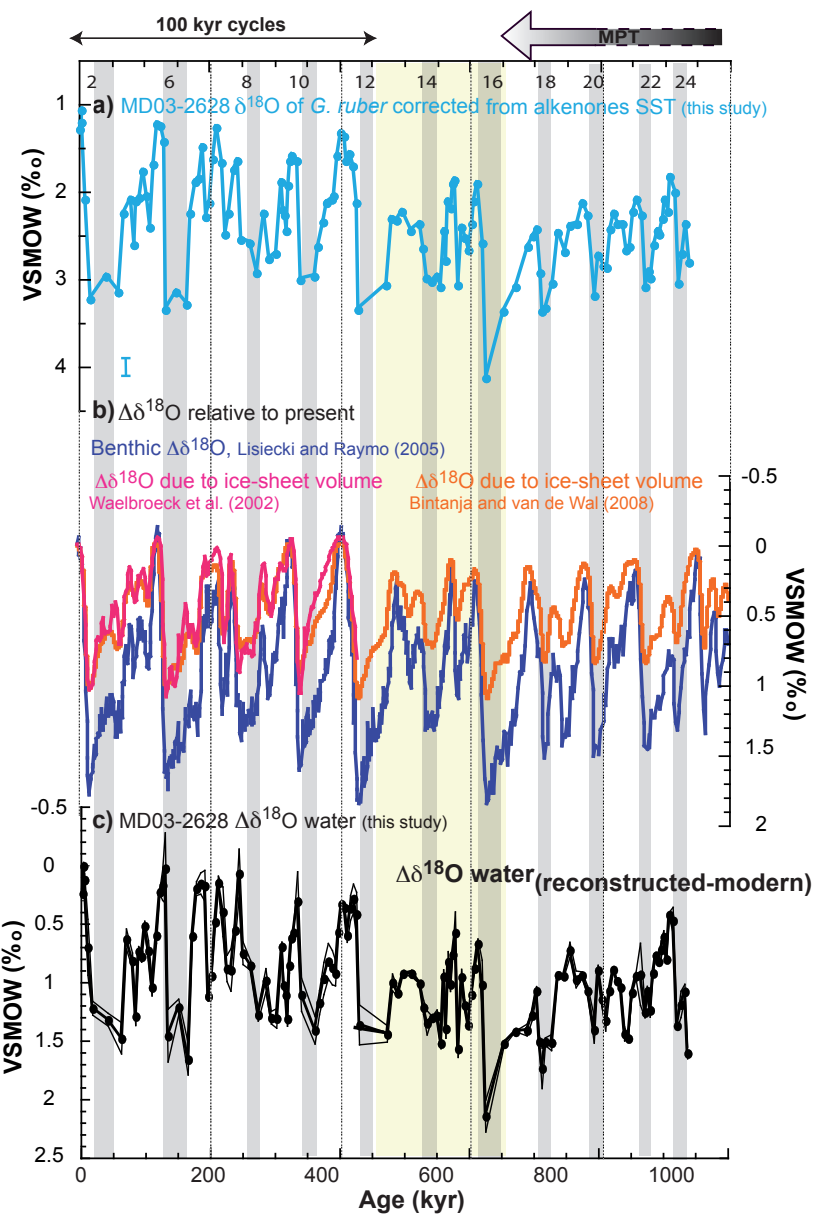

Fig. 6. The calculation steps for the correction procedure for MD03$2628 \delta^{18} \mathrm{O}$ for Globigerinoides ruber. (a) The core MD03-2628 $\delta^{18} \mathrm{O}$ record (blue curve and dots) corrected for temperature effects using sea-surface temperatures (from the $U_{37}^{K^{\prime}}$ index) and the equation of Mulitza et al. (2003). The error bar at the left shows the error in the calculation due to SST uncertainty. (b) The global oceanic $\Delta \delta^{18} \mathrm{O}$ relative to the present; the global benthic $\Delta \delta^{18} \mathrm{O}$ stack from Lisiecki and Raymo (2005) is shown in dark blue. From this record, Bintanja and van de Wal (2008) extracted the ice-volume effect (IVE, orange curve) in global $\Delta \delta^{18} \mathrm{O}$. The IVE effect was also recontructed by Waelbroeck et al. (2002) (pink curve). See the text for calculation details. (c) Variations in the $\delta^{18} \mathrm{O}$ of seawater relative to modern values (noticed $\Delta \delta^{18} \mathrm{O}$ ) at the core MD03-2628 location calculated using the records in (a) and (b). The black bold line is the average of a global IVE correction from Waelbroeck et al. (2002) and Bintanja and van de Wal (2008). The standard deviation is indicated by the thin lines and includes the variability of both IVE reconstructions as well as an uncertainty of $\pm 2.5 \mathrm{ka}$ on the core MD03-2628 age model. See the text for calculation details. Light gray bars, even numbers, and yellow area are the same as in Fig. 4. 
As discussed in Sect. 4.2., differences between SST records in the Caribbean Sea are documented and may contribute to the variability observed in the calculated $\delta^{18} \mathrm{O}$ of seawater. However, on glacial-interglacial timescales, the temperature signal only accounts for approximately $0.2 \%$, on average, of the total amplitude of the $\delta^{18} \mathrm{O}$ of seawater change $(1.46 \%$ ) during Terminations. Additionally, the long-term trend observed for the $\delta^{18} \mathrm{O}$ of $G$. ruber and for the calculated $\delta^{18} \mathrm{O}$ of seawater is not documented in SST reconstructions from the Caribbean Sea. Therefore, we believe that the discrepancies between the different paleotemperature reconstructions have little influence on the variability for the $\delta^{18} \mathrm{O}$ of seawater.

As a second step, we corrected the MD03-2628 $\delta^{18} \mathrm{O}$ of seawater from global ice volume changes. For the last $430 \mathrm{ka}$, two reconstructions for the ice volume effect (IVE) obtained from Waelbroeck et al. (2002) and Bintanja and van de Wal (2008) were used (Fig. 6b). In general, good agreement was observed between the IVE curves for the last $430 \mathrm{ka}$ (Fig. 6b). We calculated the different $\delta^{18}$ O IVE's provided within the records of Bintanja and van de Wal (2008) and Waelbroeck et al. (2002) by including the age model uncertainty of $\pm 2.5 \mathrm{ka}$ for core MD03-2628. We used these different estimations to correct the $\delta^{18} \mathrm{O}$ of seawater at the core MD03-2628 site from the IVE. At the studied temporal resolution, a shift of $\pm 2.5 \mathrm{ka}$ does not affect the phase relationships between the different $\delta^{18} \mathrm{O}$ IVE reference curves and core MD03-2628 $\delta^{18} \mathrm{O}$ and SST records. Finally, the calculated $\delta^{18} \mathrm{O}$ of seawater takes into account the core MD032628 age model uncertainty and the variability induced using two different IVE corrections. For an easier comparison, here, we present the difference between the $\delta^{18} \mathrm{O}$ of seawater in the past and the $\delta^{18} \mathrm{O}$ of modern seawater $(1.01 \%$ ) , indicated as $\Delta \delta^{18} \mathrm{O}$ (Fig. 6c). As expected, the uncertainties are higher during glacial stages, when sedimentation rates are lower.

The conversion for the $\delta^{18} \mathrm{O}$ of seawater into paleo-SSS values may be uncertain due to a lack of information regarding the temporal evolution for the $\delta^{18} \mathrm{O}$ of the seawater/SSS relationship (that is the $\delta^{18} \mathrm{O}_{\text {seawater }}=0.263( \pm 0.06) \cdot \mathrm{S}$ $8.57( \pm 1.99)$ at the core site if we consider calibrations from the Caribbean Sea and the Tropical Atlantic of Watanabe et al., 2001, Steph et al., 2006, and Regenberg et al., 2009). Therefore, we decided to discuss the change in $\Delta \delta^{18} \mathrm{O}$ as a proxy for variations in SSS relative to modern conditions (Fig. 6c). The $\Delta \delta^{18} \mathrm{O}$ record exhibited a glacial/interglacial pattern with high and low values during glacial and interglacial stages, respectively, for the last $940 \mathrm{ka}$ (Fig. 6c). Average interglacial values were $0.5 \% \circ\left( \pm 0.05 \%, 1 \sigma_{m}, n=37\right)$ for the last $450 \mathrm{ka}$, and $0.95 \%$ ( $\left( \pm 0.05 \%, 1 \sigma_{m}, n=24\right)$ for the 940-650 ka time-interval, resulting in a $\Delta \delta^{18} \mathrm{O}$ difference between the two periods of $0.45 \% \circ\left( \pm 0.07 \%\right.$ o, $\left.1 \sigma_{\text {sum }}\right)$. On the contrary, we observed a trend of nearly constant $\Delta \delta^{18} \mathrm{O}$ for all of the glacial stages throughout the record, with average values of $1.36 \% \circ\left( \pm 0.07 \% o, 1 \sigma_{m}, n=12\right)$ and $1.26 \%$ o
( $\pm 0.07 \%$ o, $1 \sigma_{m}, n=15$ ), from 940 to $650 \mathrm{ka}$ and from 450 to $0 \mathrm{ka}$, respectively. Hereafter, we refer to an average glacial $\Delta \delta^{18} \mathrm{O}$ value of $1.31 \%$ o $\left( \pm 0.09 \%\right.$ o, $\left.1 \sigma_{\text {sum }}\right)$ for both timeintervals.

On glacial-interglacial timescales, variations in the $\Delta \delta^{18} \mathrm{O}$ from -0.35 to $0.65 \%$ o have been described for the last $130 \mathrm{ka}$ in the Caribbean Sea (Schmidt et al., 2004). For the same time interval, $\Delta \delta^{18} \mathrm{O}$ results ranged from -0.02 and $1.5 \%$ o. A higher $\Delta \delta^{18} \mathrm{O}$ amplitude of change in core MD03-2628 may be related to a less pronounced variability in the SST record when compared to previous studies, mainly due to the low resolution of core MD03-2628 sampling and a decrease in sedimentation rates during glacial stages (Fig. 5). In spite of the difference in the $\Delta \delta^{18} \mathrm{O}$ amplitude, the same trend was found in both reconstructions with high values during glacials and low values during interglacials. Additionally, the average glacial/interglacial difference for core MD03-2628 $\Delta \delta^{18} \mathrm{O}$ resulted in $0.8 \%$ o $\left( \pm 0.1 \%, 1 \sigma_{\text {sum }}\right)$, in good agreement with the amplitudes of 0.5 and $0.8 \%$ as determined for the last two glacial Terminations in the Caribbean Sea, respectively (Schmidt et al., 2004), and with a study in the tropical Atlantic for the last Termination (Wolff et al., 1998).

\section{Discussion}

Reconstruction for the regional $\Delta \delta^{18} \mathrm{O}$ of seawater in the Northern Caribbean Sea has revealed two major trends - a marked glacial/interglacial pattern spanning the last $940 \mathrm{ka}$ and a shift toward lower surface water $\Delta \delta^{18} \mathrm{O}$ during interglacial stages over the last $450 \mathrm{ka}$ (Fig. 7a). In both cases the results are interpreted as changes in the salinity budget at the core location. After validating our reconstructions, the climate mechanisms responsible for these hydrologic changes and their implications are discussed according to the following main lines:

1. Processes influencing the ITCZ location on glacialinterglacial timescales. We refer to the evidence for the ITCZ migration in paleoclimatic records and discuss the mechanisms involved based on modeling results. Changes in the cross-equatorial transport of salt and heat into the North Atlantic associated with the ITCZ migration, and their related consequences on the AMOC, are also considered;

2. Using the mechanisms pointed out for the glacialinterglacial timescale, we discuss the possible causes and consequences of an ITCZ migration for interglacial stages spanning the last $450 \mathrm{ka}$, following the MPT. We explore changes in oceanic and atmospheric heat transfers in particular that may have been associated with ITCZ movement, and examine how these different processes may have contributed to the amplification of the climate cycles after the MPT. 


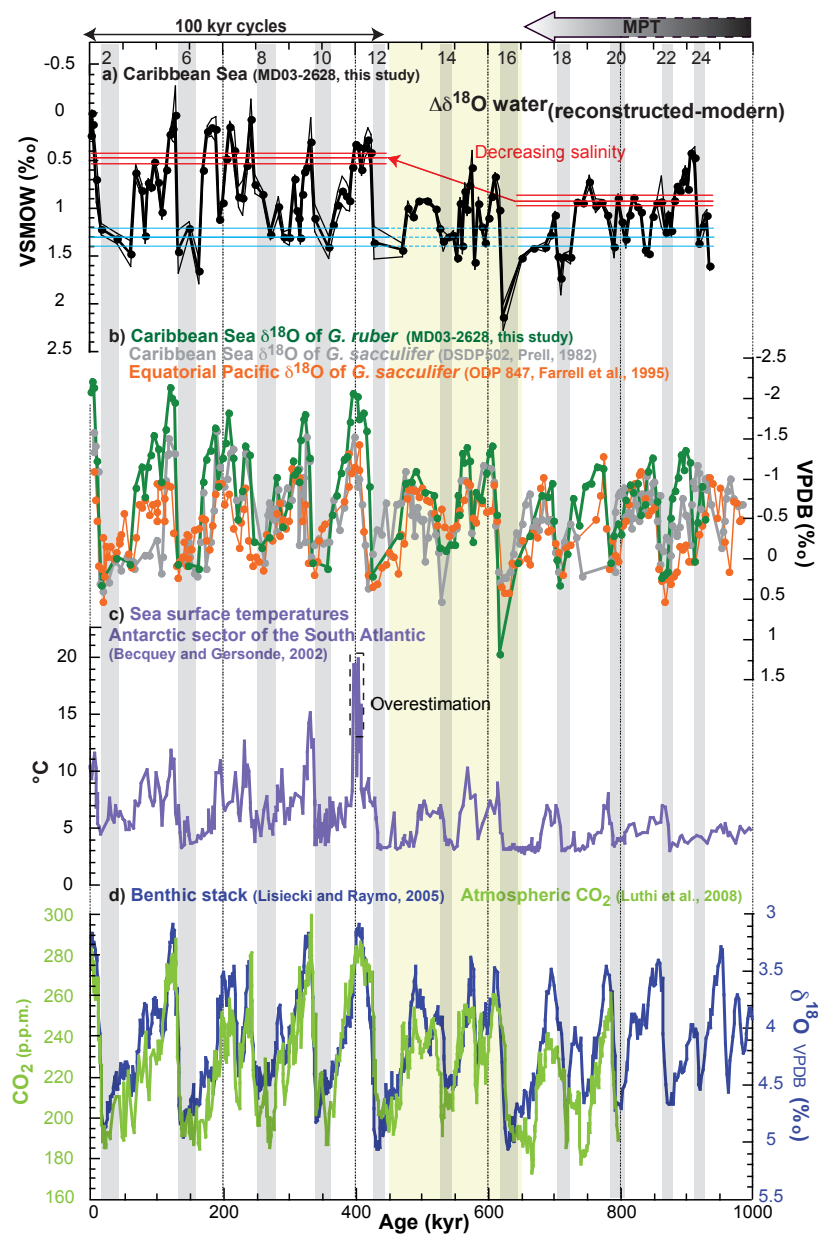

Fig. 7. (a) Mean variations for the $\delta^{18} \mathrm{O}$ of seawater relative to modern values (noticed $\Delta \delta^{18} \mathrm{O}$ ) at the core MD03-2628 location, as a proxy for past sea-surface salinities (SSS) (the black bold line and full circles, the thin lines indicate the standard deviation). The light blue bold line represents the average glacial values for the 950-650 and the $450-0 \mathrm{ka}$ time interval. The thin blue lines are the error at $1 \sigma_{m}$. The red bold lines represent, for each time interval (950-650 and $450-0 \mathrm{ka}$ ), the associated mean $\Delta \delta^{18} \mathrm{O}$ value for interglacial stages (thin red lines exhibit the error given by $1 \sigma_{m}$ ). The red arrow indicates the shift in past-SSS values for interglacial stages occuring after $650 \mathrm{ka}$. (b) A comparison between the planktonic $\delta^{18} \mathrm{O}$ records of core MD03-2628 (green curve and dots, this study) with the $\delta^{18} \mathrm{O}$ of G. sacculifer records from the Southern Caribbean Sea (DSDP 502, Fig. 1a, Prell, 1982, gray curve and dots), and the Equatorial Pacific (ODP 847, Fig. 1a, Farell et al., 1995, orange curve and dots). (c) The sea-surface temperature record from the Antarctic sector of the South Atlantic (core ODP 1090, Becquey and Gersonde, 2002). (d) The global benthic $\delta^{18} \mathrm{O}$ record from Lisiecki and Raymo (2005) in dark blue, and past atmospheric $\mathrm{CO}_{2}$ concentrations in light green (Luthi et al., 2008). Light gray bars, even numbers, and yellow area are the same as in Fig. 4.

\subsection{The validity of $\Delta \delta^{18} \mathrm{O}$ reconstructions}

\subsubsection{Glacial/interglacial $\Delta \delta^{18} O$ changes}

The glacial/interglacial pattern for the $\Delta \delta^{18} \mathrm{O}$ record in core MD03-2628 is clearly documented for the entire record, except for MIS 20 and 22 (Fig. 7a). Even if the mean $\Delta \delta^{18} \mathrm{O}$ value changed over time (see below), glacial/interglacial variations of $\Delta \delta^{18} \mathrm{O}$ were maintained downcore, suggesting that the surface water salinity increase in the northern Caribbean Sea during glacial stages was a recurrent feature of the last million years. Similar patterns have previously been described for the last glacial/interglacial cycle in the Caribbean Sea (Schmidt et al., 2004) and in the western tropical Atlantic for the last $350 \mathrm{ka}$ (Dürkoop et al., 1997). Under modern conditions, the northern position of the ITCZ during boreal summer modulates the freshwater supply to the studied area and, thus, the SSS variability (see Sect. 2.2). The main process for explaining an increase in SSS at the core site is a southern position for the ITCZ that would prevent direct and indirect freshwater supplies during glacial periods. Evidence for southward displacement has already been determined in other paleoclimatic records from the same area (e.g., Schmidt et al., 2004; Ziegler et al., 2008 and references therein). Additionally, it is generally accepted that glacial stages are associated with a reduced AMOC (e.g., Stouffer et al., 2006; Lynch-Stieglitz et al., 2007). Therefore, a reduced cross-equatorial flow would keep salty surface waters at low latitudes rather than transport them to the high latitudes of the northern Atlantic (Crowley, 1992). Such a feature is found in the core MD03-2628 $\Delta \delta^{18} \mathrm{O}$ record, which reflects an increase in salinity during glacial periods spanning the last $940 \mathrm{ka}$, in agreement with previous modelling studies and paleoceanographic records from tropical areas (Rühlemann et al., 2004; Dahl et al., 2005) (Fig. 7a).

\subsubsection{Long-term $\Delta \delta^{18} \mathrm{O}$ shifts}

The other remarkable feature in the $\Delta \delta^{18} \mathrm{O}$ record of core MD03-2628 is a shift toward lower values occurring during interglacial stages after $450 \mathrm{ka}$ (Fig. 7a). This trend in local salinity in the northern Caribbean Sea is robust and is not an artifact produced by the SST reconstruction (Figs. 4b and 5), and/or by the global oceanic $\delta^{18} \mathrm{O}$ (Fig. 6). The SST record in core MD03-2628 does not show any shift between $650 \mathrm{ka}$ and $450 \mathrm{ka}$ (Fig. 4b), a feature that is supported by other tropical SST records for the last million years (even if other areas are controlled by different climate processes) (de GaridelThoron, 2007; Liu et al., 2008). We have shown that the trend observed in the $\Delta \delta^{18} \mathrm{O}$ record already exists in the seawater $\delta^{18} \mathrm{O}$ record reconstructed only by correcting the $\delta^{18} \mathrm{O}$ of $G$. ruber for SST without considering the global mean oceanic $\delta^{18} \mathrm{O}$ (Fig. 6a).

The effect of long-term changes in the preservation state of planktonic foraminiferal tests on $\delta^{18} \mathrm{O}$ values can be ruled out 
since Sepulcre et al. (2009) have shown that calcium carbonate minerals were well-preserved in core MD03-2628 over the last $940 \mathrm{ka}$, as indicated by high amounts of metastable fine aragonite as well as magnesian calcite.

The comparison between core MD03-2628 $\delta^{18} \mathrm{O}$ results and other planktonic records supports the fact that the observed trend is related to Caribbean water hydrology. The Globigerinoides sacculifer $\delta^{18} \mathrm{O}$ record at site ODP 847 in the Eastern Equatorial Pacific (Fig. 1a, Farrell et al., 1995) does show constant mean values for the last million years (Fig. 7b). On the other hand, the G. sacculifer $\delta^{18} \mathrm{O}$ record from core DSDP 502 obtained from the Caribbean Sea (Figs. 1a and 7b) also shows a significant difference (of approximately $0.4 \%$ o in mean $\delta^{18} \mathrm{O}$ values between the late and early Quaternary (Prell, 1982).

Therefore, we suggest that the observed shift in the $\Delta \delta^{18} \mathrm{O}$ of core MD03-2628 reflects changes in the regional salinity of the Caribbean Sea mainly during interglacial stages (Fig. 7a). The ITCZ may have migrated farther northward during interglacials over the last $450 \mathrm{ka}$ (as compared to the period before $650 \mathrm{ka}$ ), explaining these local hydrologic changes. A northward position would bring more freshwater to the site and cause a salinity decrease during interglacials, as observed during modern late summer conditions (Figs. 2 and 3). An alternate explanation would be an increase in ITCZ intensity following the MPT. Warmer SSTs in the Northern tropics could have resulted in more intense atmospheric convection and thus, more intense rainfall resulting in reduced interglacial SSS. However, there is no clear long-term trend observed in SST records from different locations of the tropical area over the MPT (de Garidel-Thoron, 2007; Liu et al., 2008). Therefore, the impact of warmer SST on the ITCZ intensity at the MPT timescale seems unlikely, and in the following, we discuss processes involved in ITCZ migration.

\subsection{Mechanisms for ITCZ migration and links with the AMOC}

The processes responsible for ITCZ migration at glacialinterglacial timescales can be inferred both from modern conditions and modelling results. The modern seasonal migration of the ITCZ is influenced by the cross-equator temperature gradient, with a relatively warm Northern Hemisphere compared to the Southern Hemisphere; this northsouth asymmetry implies that the ITCZ lies within the relatively warm Northern Hemisphere for most of the year (e.g., Chiang et al., 2002 and 2003).

As mentioned previously by several authors (Chiang et al., 2003; Broccoli et al., 2006; Stouffer et al., 2006), an interhemispheric temperature contrast was initiated during periods of reduced AMOC and played an important role in ITCZ displacement in the past on glacial/interglacial timescales. A recent study focused on simulations of the last glacial maximum. Special emphasis on the ITCZ has shown that a south- ward shift of the ITCZ, resulting from an increased equator to pole temperature gradient in the Northern Hemisphere associated with glacial boundary conditions, is a robust feature, since it has been observed in several model outputs (Braconnot et al., 2007). The associated oceanic response in the tropical Atlantic is a warming of thermocline waters that results from the decreased strength of the northward flowing current in surface and thermocline waters (Rühlemann et al., 2004; Dahl et al., 2005). Warm and salty waters stay in the tropics without being exported to the north (Dahl et al., 2005; Wan et al., 2010).

The interesting feature is that the ITCZ migration, which is related to a change in the cross-equator temperature gradient due to a reduced AMOC, has been mentioned for different timescales and corresponds to different modes of climate variability and thermohaline circulation (Mix et al., 1986; Dürkoop et al., 1997; Schmidt et al., 2004; Ziegler et al., 2008); and occurs during rapid climate changes (e.g., Heinrich events) (Rühlemann et al., 1999; Vidal et al., 1999, Schmidt et al., 2004 and 2006b; Weldeab et al., 2006; Ziegler et al., 2008). Similar mechanisms for different timescales may be involved and may help to explain ITCZ migration in the past. We propose that North Atlantic variability interacted with the ITCZ position over the MPT.

\subsection{Links between the ITCZ location and climate changes associated with the MPT}

One possible interpretation for the low SSS estimates during interglacial stages spanning the last $450 \mathrm{ka}$ is a northward shift of the ITCZ. The comparison between the $\delta^{18} \mathrm{O}$ records of core MD03-2628 and core DSDP 502 suggests that ITCZ migration influenced the Caribbean Sea overall (Figs. 1a and 7b). In contrast, the $\delta^{18} \mathrm{O}$ record of core ODP 847 obtained from the Eastern Equatorial Pacific Ocean did not record lower $\delta^{18} \mathrm{O}$ values during interglacials spanning the last $450 \mathrm{ka}$ (Fig. 7b). Under modern conditions, core ODP 847 lies at the southernmost limit of the ITCZ's influence (Fig. 1a); therefore, a northward ITCZ migration would not influence the core ODP 847 site.

One way to explain the northward ITCZ migration is a change in the cross-equator temperature gradient that may be related to an increased northward oceanic heat transfer during the interglacials of the past $450 \mathrm{ka}$ (Trenberth and Caron, 2001). Evidence of enhanced oceanic mass transport can be found in results obtained from the South Atlantic (Peeters et al., 2004). Faunal assemblages in the Cape Basin were used to reconstruct the so-called "Agulhas leakage" (AL), an index for heat and salt export from the Indian Ocean into the Atlantic Ocean. The temporal evolution of this index clearly shows a marked variability with 100 ka-cycles with an enhanced export of warm and salty waters into the south Atlantic during the past five glacial Terminations (Peeters et al., 2004). The strong relationship between the efficiency of the AL and the strength of the AMOC is supported by 
observations in the modern ocean and by model simulations (Knorr and Lohmann, 2003; Biastoch et al., 2008). The intensity of the AL depends on the location of Southern Ocean oceanographic fronts (SOF) and the related Southern Hemisphere westerlies (Rouault et al., 2009; Biastoch et al., 2009). A poleward migration of the SOF induces changes in wind stress that cause the resumption of the Agulhas currrent and, as a consequence, intense leakage from the Indian Ocean to the Atlantic Basin. At glacial-interglacial timescales, influence of the SOF migration on the AL and its impacts on the AMOC has been invoked for extreme glacial stages (Bard and Rickaby, 2009). On a longer timescale, a study based on past SST from the South Atlantic spanning the MPT has pointed to a shift toward higher SST values during interglacial stages for the last $450 \mathrm{ka}$, as compared to older interglacial stages (Becquey and Gersonde, 2002, Fig. 7c). The abrupt change in SST values reflects a southernmost SOF location, implying a stronger AL for the last five interglacial stages as compared to interglacials older than $650 \mathrm{ka}$ (Becquey and Gersonde, 2002, Fig. 7c). These long-term changes in the SOF location may have induced a more vigorous AMOC during interglacial stages of the last $450 \mathrm{ka}$. An enhanced northward oceanic transfer during the interglacial stages could have promoted more intense heat transport to high latitudes, and therefore, warming of the Northern Hemisphere (Chiang et al., 2003; Braconnot et al., 2007; Toggweiler, 2009). As a result, the ITCZ could have moved northward. Finally, the combination of a northernmost ITCZ location and an increase in oceanic heat transfer may be involved in the amplification of climate cycles during the last $450 \mathrm{ka}$ (Fig. 7d).

A final piece of evidence for a long-term migration of the SOF during the MPT is derived from the change in atmospheric $\mathrm{CO}_{2}$. Model simulations have shown links between the location of the SOF and atmospheric $\mathrm{CO}_{2}$ through the oceanic carbon pump efficiency (Saenko et al., 2005; Toggweiler et al., 2006; Toggweiler and Russell, 2008; Köhler and Bintanja, 2008). The recent record of atmospheric $\mathrm{CO}_{2}$ from the EPICA spanning the last 800 ka clearly shows a difference in the glacial-interglacial amplitude for $\mathrm{CO}_{2}$ changes between the last five climate cycles, and for periods older than $450 \mathrm{ka}$ (Luthi et al., 2008, Fig. 7d). Profound changes in the carbon cycle may need to be invoked in order to explain the transition of the overall climate system from the 41-ka to the 100-ka world.

\section{Conclusions}

The goal of this study was to evaluate the impact of changes in the climate system following the Mid-Pleistocene Transition (MPT) on the tropical Atlantic Ocean by evaluating past variations in the hydrologic cycle in the Northern Caribbean Sea. In core MD03-2628, we estimated past sea surface salinities (SSS) using reconstructions of the past changes of seawater $\delta^{18} \mathrm{O}$ relative to modern conditions $\left(\Delta \delta^{18} \mathrm{O}\right)$. The $\delta^{18} \mathrm{O}$ of seawater was obtained by combining the alkenone sea-surface temperature record with the $\delta^{18} \mathrm{O}$ of $G$. ruber and by applying a correction for the ice-sheet volume effect over the last $940 \mathrm{ka}$. Today, the main control on SSS at the core site is the modern seasonal inter-tropical convergence zone (ITCZ) migration. Variations in the $\Delta \delta^{18} \mathrm{O}$ displayed a pattern of lower and higher SSS during interglacial and glacial stages, respectively, over the past $940 \mathrm{ka}$. Glacial stage values for $\Delta \delta^{18} \mathrm{O}$ were nearly constant for the last $940 \mathrm{ka}$, whereas interglacial values for the 940-650 ka time-period were higher than for the 450-0 ka interval.

The core MD03-2628 $\Delta \delta^{18} \mathrm{O}$ record allowed us to document the relationships between the low latitude hydrologic cycle and the Atlantic Meridional Overturning Circulation (AMOC) at the glacial/interglacial timescale over the last $940 \mathrm{ka}$. We propose that for all glacial periods during the last $940 \mathrm{ka}$, the southward position of the ITCZ induced an increase in SSS at the studied site, in association with a reduced AMOC, keeping warm and salty waters at low latitudes, as previously suggested for the last glacial period. On a longer timescale, the $\Delta \delta^{18} \mathrm{O}$ results highlight the response of tropical areas to climate changes associated with the MPT. A shift in the $\Delta \delta^{18} \mathrm{O}$ values reflects the northward migration of the ITCZ during the last five interglacial periods, when compared to the time-period before $650 \mathrm{ka}$. Northward movement during interglacial stages could have been associated with an enhanced cross-equatorial oceanic transport, as supported by evidence from the South Atlantic. The combination of enhanced northward atmospheric and oceanic transfers could have participated in the amplification of climate cycles during the last $450 \mathrm{ka}$.

\section{Supplementary material related to this article is available online at: http://www.clim-past.net/7/75/2011/ cp-7-75-2011-supplement.pdf.}

Acknowledgements. Paleoclimate work at CEREGE is supported by grants from the CNRS, the ANR-PICC, the Gary Comer Foundation for Science and Education, the European Community (Project Past4Future) and the Collège de France. We are grateful to Corinne Sonzogni for technical assistance.

Edited by: H. Fischer

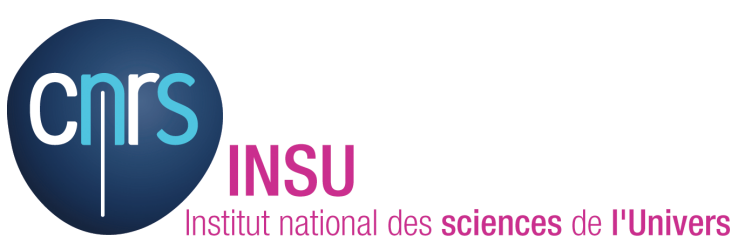

The publication of this article is financed by CNRS-INSU. 


\section{References}

Bard, E. and Rickaby, R. E. M.: Migration of the subtropical front as a modulator of glacial climate, Nature, 460, 380-393, 2009.

Becquey, S. and Gersonde, R.: Past hydrographic and climatic changes in the Subantarctic Zone of the South Atlantic - The Pleistocene record from ODP Site 1090, Palaeogeogr. Palaeocl., 182, 221-239, 2002.

Bemis, B. E., Spero, H. J., Bijma, J., and Lea, D. W.: Reevaluation of the oxygen isotopic composition of planktonic foraminifera: Experimental results and revised paleotemperature equations, Paleoceanography, 13, 150-160, 1998.

Berger, A. X., Li, S., and Loutre, M.-F.: Modelling Northern Hemisphere ice volume over the last $3 \mathrm{Ma}$, Quaternary Sci. Rev., 18, 1-11, 1999.

Biastoch, A., Boning, C. W., and Lutjeharms, J. R. E.: Agulhas leakage dynamics affects decadal variability in Atlantic overturning circulation, Nature, 456, 489-492, 2008.

Biastoch, A., Boning, C. W., Schwarzkopf, F. U., and Lutjeharms, J. R. E.: Increase in Agulhas leakage due to poleward shift of Southern Hemisphere westerlies, Nature, 462, 495-498, 2009.

Bintanja, R. and van de Wal, R. S. W.: North American ice-sheet dynamics and the onset of 100000 -year glacial cycles, Nature, 454, 869-872, 2008.

Braconnot, P., Otto-Bliesner, B., Harrison, S., Joussaume, S., Peterchmitt, J.-Y., Abe-Ouchi, A., Crucifix, M., Driesschaert, E., Fichefet, Th., Hewitt, C. D., Kageyama, M., Kitoh, A., Loutre, M.-F., Marti, O., Merkel, U., Ramstein, G., Valdes, P., Weber, L., Yu, Y., and Zhao, Y.: Results of PMIP2 coupled simulations of the Mid-Holocene and Last Glacial Maximum -Part 2: feedbacks with emphasis on the location of the ITCZ and mid- and high latitudes heat budget, Clim. Past, 3, 279-296, doi:10.5194/cp-3279-2007, 2007.

Broccoli, A. J., Dahl, K. A., and Stouffer, R. J.: Response of the ITCZ to Northern Hemisphere cooling, Geophys. Res. Lett., 33, L01702, doi:10.1029/2005GL024546, 2006.

Broecker, W. S., Bond, G., Klas, M., Bonani, G., and Wolfli, W. A.: A salt oscillator in the glacial Atlantic?, 1. The concept. Paleoceanography, 5, 469-477, 1990.

Cheng, H., Edwards, R. L., Broecker, W. S., Denton, G. H., Kong, X. G., Wang, Y. J., Zhang, R., and Wang, X. F: Ice Age Terminations, Science, 326, 248-252, 2009.

Chérubin, L. M. and Richardson, P. L.: Caribbean current variability and the influence of the Amazon and Orinoco freshwater plumes, Deep-Sea Res. Pt. I, 54, 1451-1473, 2007.

Chiang, J. C. H., Kushnir, Y., and Giannini, A.: Deconstructing Atlantic Intertropical Convergence Zone variability: Influence of the local cross-equatorial sea surface temperature gradient and remote forcing from the eastern equatorial Pacific, J. Geophys. Res.-Atmos., 107, D1, doi:10.1029/2000JD000307, 2002.

Chiang, J. C. H., Biasutti, M., and Battisti, D. S.: Sensitivity of the Atlantic Intertropical Convergence Zone to Last Glacial Maximum boundary conditions, Paleoceanography, 18, 1094, doi:10.1029/2003PA000916, 2003.

Clark, P. U. and Pollard, D.: Origin of the Middle Pleistocene transition by ice sheet erosion of regolith, Paleoceanography, 13, 1-9, 1998.

Clark, P. U., Archer, D., Pollard, D., Blum, J. D., Rial, J. A., Brovkin, V., Mix, A. C., Pisias, N. G., and Roy, M.: The middle Pleistocene transition: characteristics. mechanisms, and implica- tions for long-term changes in atmospheric $p \mathrm{CO}_{2}$, Quaternary Sci. Rev., 25, 3150-3184, 2006.

Conte, M. H., Sicre, M. A., Rühlemann, C., Weber, J. C., Schulte, S., Schulz-Bull, D., and Blanz, T.: Global temperature calibration of the alkenone unsaturation index (U-37(K')) in surface waters and comparison with surface sediments, Geochem. Geophy. Geosy., 7, Q02005, doi:10.1029/2005GC001054, 2006.

Crowley, T. J.: North Atlantic Deep Water cools the Southern Hemisphere, Paleoceanography, 7, 489-497, 1992.

Dahl, K., Broccoli, A., and Stouffer, R.: Assessing the role of North Atlantic freshwater forcing in millennial scale climate variability: a tropical Atlantic perspective, Clim. Dynam., 24, 325-346, 2005.

da Silva, A., Young, A. C., and Levitus, S.: Atlas of Surface Marine Data 1994, Volume 1: Algorithms and Procedures, NOAA Atlas NESDIS, 6, US Department of Commerce, Washington, DC, http://iridl.ldeo.columbia.edu/SOURCES/.DASILVA/, 1994.

de Garidel-Thoron, T.: Paleoceanography records, Early Pleistocene, Encyclopedia of Quaternary Science, 1785-1793, 2007.

Dürkoop, A., Hale, W., Mulitza, S., Patzold, J., and Wefer, G.: Late Quaternary variations of sea surface salinity and temperature in the western tropical Atlantic: Evidence from delta O-18 of Globigerinoides sacculifer, Paleoceanography, 12, 764-772, 1997.

Farrell, J. W., Murray, D. W., McKenna, V. S., and Ravelo, A. C.: Upper ocean temperature and nutrient contrasts inferred from Pleistocene planktonic foraminifer $\delta^{18} \mathrm{O}$ and $\delta^{13} \mathrm{C}$ in the Eastern Equatorial Pacific, Proceedings of ODP, Sci. Res., 138, 289-319, 1995.

Fratantoni, D. M., Zantopp, R. J., Johns, W. E., and Miller, J. L.: Updated bathymetry of the Anegada-Jungfern Passage complex and implications for Atlantic inflow to the abyssal Caribbean Sea, J. Mar. Res., 55, 847-860, 1997.

Gordon, A. L.: Oceanography - Communication between oceans, Nature, 382, 399-400, 1996.

Hastings, D. W., Russell, A. D., and Emerson, S. R.: Foraminiferal magnesium in Globeriginoides sacculifer as a paleotemperature proxy, Paleoceanography, 13, 161-169, 1998.

Haug, G. H. and Tiedemann, R.: Effect of the formation of the Isthmus of Panama on Atlantic Ocean thermohaline circulation, Nature, 393, 673-676, 1998.

Haug, G. H., Tiedemann, R., Zahn, R., and Ravelo, A. C.: Role of Panama uplift on oceanic freshwater balance, Geology, 29, 207210, 2001.

Haug, G. H., Gunther, D., Peterson, L. C., Sigman, D. M., Hughen, K. A., and Aeschlimann, B.: Climate and the collapse of Maya civilization, Science, 299, 1731-1735, 2003.

Head, M. J. and Gibbard, P. L.: Early-Middle Pleistocene transitions: an overview and recommendation for the defining boundary, in: Early-Middle Pleistocene Transitions: The Land-Ocean Evidence, edited by: Head, M. J. and Gibbard, P. L., Geological Society of London, Special Publications, 247, 1-8, 2005.

Hellweger, F. L. and Gordon, A. L.: Tracing Amazon River water into the Caribbean Sea, J. Mar. Res., 60, 537-549, 2002.

Hernandez-Guerra, A. and Joyce, T. M.: Water masses and circulation in the surface layers of the Caribbean at 66 degrees W, Geophys. Res. Lett., 27, 3497-3500, 2000.

Hoogakker, B. A. A., Rohling, E. J., Palmer, M. R., Tyrrell, T., and Rothwell, R. G.: Underlying causes for long-term global ocean delta C-13 fluctuations over the last 1.20 Myr, Earth Planet. Sc. 
Lett., 248, 15-29, 2006.

Hu, C. M., Montgomery, E. T., Schmitt, R. W., and Müller-Karger, F. E.: The dispersal of the Amazon and Orinoco River water in the Tropical Atlantic and Caribbean Sea: Observation from space and S-PALACE floats, Deep-Sea Res. Pt. II, 51, 11511171, 2004.

Hüls, M. and Zahn, R.: Millennial-scale sea surface temperature variability in the western Tropical North Atlantic from planktonic foraminiferal census counts, Paleoceanography, 15, 659678,2000

Johns, W. E., Townsend, T. L., Fratantoni, D. M., and W. D.Wilson: On the Atlantic inflow to the Caribbean Sea, Deep Sea Res., Part I, 49, 211-243, 2002.

Kameo, K., Shearer, M. C., Droxler, A. W., Mita, I., Watanabe, R., and Sato, T.: Glacial-interglacial surface water variations in the Caribbean Sea during the last 300 ky based on calcareous nannofossil analysis, Palaeogeogr. Palaeocl., 212, 65-76, 2004.

Kawamura, K., Parrenin, F., Lisiecki, L., Uemura, R., Vimeux, F., Severinghaus, J. P., Hutterli, M. A., Nakazawa, T., Aoki, S., Jouzel, J., Raymo, M. E., Matsumoto, K., Nakata, H., Motoyama, H., Fujita, S., Goto-Azuma, K., Fujii, Y., and Watanabe, O.: Northern Hemisphere forcing of climatic cycles in Antarctica over the past 360000 years, Nature, 448, 912-914, 2007.

Köhler, P. and Bintanja, R.: The carbon cycle during the Mid Pleistocene Transition: the Southern Ocean Decoupling Hypothesis, Clim. Past, 4, 311-332, doi:10.5194/cp-4-311-2008, 2008.

Knorr, G. and Lohmann, G.: Southern Ocean origin for the resumption of Atlantic thermohaline circulation during deglaciation, Nature, 424, 532-536, 2003.

Levitus, S. and Boyer, T.: World Ocean Atlas 1994, US Department of Commerce, Washington DC, http://ingrid.ldeo.columbia.edu/ SOURCES/.LEVITUS/, 1994.

Lisiecki, L. E. and Raymo, M. E.: A Pliocene-Pleistocene stack of 57 globally distributed benthic delta O-18 record, Paleoceanography, 20, PA1003, doi:10.1029/2004PA001071, 2005.

Liu, Z., Cleaveland, L. C., and Herbert, T. H.: Early onset of 100kyr cycles in Pleistocene tropical SST records, Earth Planet. Sc. Lett., 265, 703-715, 2008.

Luthi, D., Le Floch, M., Bereiter, B., Blunier, T., Barnola, J. M., Siegenthaler, U., Raynaud, D., Jouzel, J., Fischer, H., Kawamura, K., and Stocker, T. F.: High-resolution carbon dioxide concentration record 650000-800000 years before present, Nature, 453, 379-382, 2008.

Lynch-Stieglitz, J., Adkins, J. F., Curry, W. B., Dokken, T., Hall, I. R., Herguera, J. C., Hirschi, J. J. M., Ivanova, E. V., Kissel, C., Marchal, O., Marchitto, T. M., McCave, I. N., McManus, J. F., Mulitza, S., Ninnemann, U., Peeters, F., Yu, E. F., and R., Zahn: Atlantic meridional overturning circulation during the Last Glacial Maximum, Science, 316, 66-69, 2007.

Martinez, J. I., Mora, G., and Barrows, T. T.: Paleoceanographic conditions in the western Caribbean Sea for the last $560 \mathrm{kyr}$ as inferred from planktonic foraminifera, Mar. Micropaleontol., 64, 177-188, 2007.

Maslin, M. A., and Ridgwell, A. J.: Mid-Pleistocene revolution and the 'eccentricity myth', in: Early-Middle Pleistocene Transitions: The Land-Ocean Evidence, edited by: Head, M. J. and Gibbard, P. L.: Geological Society of London, Special Publications, 247, 19-34, 2005.

McClymont, E. L. and Rosell-Mele, A.:Links between the onset of modern Walker circulation and the mid-Pleistocene climate transition, Geology, 33, 389-392, 2005.

McClymont, E. L., Rosell-Mele, A., Haug, G. H., and Lloyd, J. M.: Expansion of subarctic water masses in the North Atlantic and Pacific oceans and implications for midPleistocene ice sheet growth, Paleoceanography, 23, PA4214, doi:10.1029/2008PA001622, 2008.

Mix, A. C., Ruddiman, W. F., and McIntyre, A.: Late Quaternary paleoceanography of the tropical Atlantic. I. Spatial variability of annual mean sea-surface temperatures 0-20000 years BP, Paleoceanography, 1, 43-66, 1986.

Mix, A. C., Pisias, N. G., Rugh, W., Wilson, J., Morey, A. E., and Hagelberg, T. K.: Benthic foraminifer stable isotope record from Site 849 (0-5 Ma): local and global climate changes, Proceedings of ODP, Sci. Res., 138, 371-412, 1995.

Morrison, J. M. and Nowlin, W. D.: General Distribution of Water Masses within the Eastern Caribbean Sea During the Winter of 1972 and Fall of 1973, J. Geophys. Res.-Oc. Atm., 87, 42074229, 1982.

Mulitza, S., Boltovskoy, D., Donner, B., Meggers, H., Paul, A., and Wefer, G.: Temperature: delta O-18 relationships of planktonic foraminifera collected from surface waters, Palaeogeogr. Palaeocl., 202, 143-152, 2003.

Müller-Karger, F. E., McClain, C. R., and Richardson, P. L.: The Dispersal of the Amazons Water, Nature, 333, 56-59, 1988.

Paillard, D., Labeyrie, L., and Yiou, P.: Macintosh program performs time-series analysis, EOS. Trans. AGU, 77, 379, 1996.

Peeters, F. J. C., Acheson, R., Brummer, G. J. A., de Ruijter, W. P. M., Schneider, R. R., Ganssen, G. M., Ufkes, E., and Kroon, D.: Vigorous exchange between the Indian and Atlantic oceans at the end of the past five glacial periods, Nature, 430, 661-665, 2004.

Prell, W. L.: Oxygen and carbon isotope stratigraphy for the Quaternary of Hole 502B: evidence for two modes of isotopic variability, Init. Rep. DSDP, 68, 455-464, 1982.

Rahmstorf, S.: The thermohaline ocean circulation: A system with dangerous thresholds?, An editorial comment, Climatic Change, 46, 247-256, 2000.

Rahmstorf, S.: Ocean circulation and climate during the past 120000 years, Nature, 419, 207-214, 2002.

Rahmstorf, S.: Thermohaline Ocean Circulation, in: , Encyclopedia of Quaternary Sciences, edited by: Elias, S. A., Elsevier, Amsterdam, 2006.

Rahmstorf, S., Crucifix, M., Ganopolski, A., Goosse, H., Kamenkovich, I., Knutti, R., Lohmann, G., Marsh, R., Mysak, L. A., Wang, Z. M., and Weaver, A. J.: Thermohaline circulation hysteresis: a model intercomparison, Geophys. Res. Lett., 32, L23605, doi:10.1029/2005GL023655, 2005.

Raymo, M. E. and Huybers, P.: Unlocking the mysteries of the ice ages, Nature, 451, 284-285, 2008.

Raymo, M., Ruddiman, W. F., Shackleton, N. J., and Oppo, D. W.: Evolution of Atlantic-Pacific delta-C13 gradients over the last 2.5 m.y., Earth Planet. Sc. Let., 97, 357-368, 1990.

Raymo, M. E., Oppo, D. W., and Curry, W.: The mid-Pleistocene climate transition: A deep sea carbon isotopic perspective, Paleoceanography, 12, 546-559, 1997.

Raymo, M. E., Lisiecki, L. E., and Nisancioglu, K. H.: Pliopleistocene ice volume, Antarctic climate, and the global delta O-18 record, Science, 313, 492-495, 2006.

Regenberg, M., Steph, S., Nurnberg, D., Tiedemann, R., and Garbe- 
Schonberg, D.: Calibrating $\mathrm{Mg} / \mathrm{Ca}$ ratios of multiple planktonic foraminiferal species with delta O-18-calcification temperatures: Paleothermometry for the upper water column, Earth Planet. Sc. Lett., 278, 324-336, 2009.

Reijmer, J. J. G. and Andresen, N.: Mineralogy and grain size variations along two carbonate margin-to-basin transects (Pedro Bank, Northern Nicaragua Rise), Sediment. Geol., 198, 327350, 2007.

Rosell-Melé, A., Bard, E., Emeis, K. C., Grimalt, J. O., Muller, P., Schneider, R., Bouloubassi, I., Epstein, B., Fahl, K., Fluegge, A., Freeman, K., Goni, M., Guntner, U., Hartz, D., Hellebust, S., Herbert, T., Ikehara, M., Ishiwatari, R., Kawamura, K., Kenig, F., de Leeuw, J., Lehman, S., Mejanelle, L., Ohkouchi, N., Pancost, R. D., Pelejero, C., Prahl, F., Quinn, J., Rontani, J. F., Rostek, F., Rullkotter, J., Sachs, J., Blanz, T., Sawada, K., Schutz-Bull, D., Sikes, E., Sonzogni, C., Ternois, Y., Versteegh, G., Volkman, J. K., and Wakeham, S.: Precision of the current methods to measure the alkenone proxy $\mathrm{U}-37\left(\mathrm{~K}^{\prime}\right)$ and absolute alkenone abundance in sediments: Results of an interlaboratory comparison study, Geochem.Geophy. Geosy., 2, 1046, doi:10.1029/2000GC000141, 2001.

Rouault, M., Penven, P., and Pohl, B.: Warming in the Agulhas Current system since the 1980's, Geophys. Res. Lett., 36, L12602, doi:10.1029/2009GL037987, 2009.

Rühlemann, C., Mulitza, S., Muller, P. J., Wefer, G., and Zahn, R.: Warming of the Tropical Atlantic Ocean and slowdown of thermohaline circulation during the last deglaciation, Nature, 402, 511-514, 1999.

Rühlemann, C., Mulitza, S., Lohmann, G., Paul, A., Prange, M., and Wefer, G.: Intermediate depth warming in the tropical Atlantic related to weakened thermohaline circulation: Combining paleoclimate data and modeling results for the last deglaciation, Paleoceanography, 19, PA1025, doi:10.1029/2003PA000948, 2004.

Rutherford, S. and D'Hondt, S.: Early onset and tropical forcing of 100000 -year pleistocene glacial cycles, Nature, 408, 72-75, 2000.

Saenko, O. A., Fyfe, J. C., and England, M. H.: On the response of the oceanic wind-driven circulation to atmospheric $\mathrm{CO}_{2}$ increase, Clim. Dynam., 25, 415-426, 2005.

Schmidt, G. A., Bigg, G. R., and Rohling, E. J.: Global Seawater Oxygen-18 Database, http://data.giss.nasa.gov/o18data/, 1999.

Schmidt, M. W., Spero, H. J., and Lea, D. W.: Links between salinity variation in the Caribbean and North Atlantic thermohaline circulation, Nature, 428, 160-163, 2004.

Schmidt, M. W., Vautravers, M. J., and Spero, H. J.: Western Caribbean sea surface temperatures during the late Quaternary, Geochem. Geophy. Geosy., 7, Q02P10, doi:10.1029/2005GC000957, 2006a.

Schmidt, M. W., Vautravers, M. J., and Spero, H. J.: Rapid subtropical North Atlantic salinity oscillations across DansgaardOeschger cycles, Nature, 443, 561-564, 2006b.

Schmieder, F., von Dobeneck, T., and Bleil, U.: The MidPleistocene climate transition as documented in the deep South Atlantic Ocean: initiation, interim state and terminal event, Earth Planet. Sc. Lett., 179, 539-549, 2000.

Schmitz, W. J. and Richardson, P. L.: On the sources of the Florida current, Deep-Sea Res., 38 (suppl.), 379-409, 1991.

Schmuker, B. and R. Schiebel, Planktic foraminifers and hydrography of the eastern and Northern Caribbean Sea, Mar. Micropale- ontol., 46, 387-403, 2002.

Schulz, K. G. and Zeebe, R. E.: Pleistocene glacial terminations triggered by synchronous changes in Southern and Northern Hemisphere insolation: The insolation canon hypothesis, Earth Planet. Sc. Lett., 249, 326-336, 2006.

Sepulcre, S., Tachikawa, K., Vidal, L., Thouveny, N., and Bard, E.: Preservation state of metastable magnesian calcite in periplatform sediment from the Caribbean Sea over the last million years, Geochem. Geophy. Geosy., 10, Q11013, doi:10.1029/2009GC002779, 2009.

Sonzogni, C., Bard, E., Rostek, F., Dollfus, D., RosellMele, A., and Eglinton, G.: Temperature and salinity effects on alkenone ratios measured in surface sediments from the Indian Ocean, Quaternary Res., 47, 344-355, 1997.

Steph, S., Tiedemann, R., Prange, M., Groeneveld, J., Nurnberg, D., Reuning, L., Schulz, M., and Haug, G. H.: Changes in Caribbean surface hydrography during the Pliocene shoaling of the Central American Seaway, Paleoceanography, 21, PA4221, doi:10.1029/2004PA001092, 2006.

Stouffer, R. J., Yin, J., Gregory, J. M., Dixon, K. W., Spelman, M. J., Hurlin, W., Weaver, A. J., Eby, M., Flato, G.M., Hasumi, H., Hu, A., Jungclaus, J. H., Kamenkovich, I. V., Levermann, A., Montoya, M., Murakami, S., Nawrath, S., Oka, A., Peltier, W. R., Robitaille, D. Y., Sokolov, A., Vettoretti, G., and S. L. Weber: Investigating the causes of the response of the thermohaline circulation to past and future climate changes, J. Clim., 19(8), 1365-1387, 2006.

Taylor, M. A., Enfield, D. B., and Chen, A. A.: Influence of the Tropical Atlantic versus the Tropical Pacific on Caribbean rainfall, J. Geophys. Res.-Oc., 107, 3127, doi:10.1029/2001JC001097, 2002.

Toggweiler, J. R.: Shifting Westerlies, Science, 323, 1434-1435, 2009.

Toggweiler, J. R. and Russell, J.: Ocean circulation in a warming climate, Nature, 451, 286-288, 2008.

Toggweiler, J. R., Russell, J. L., and Carson, S. R.: Midlatitude westerlies, atmospheric $\mathrm{CO}_{2}$, and climate change during the ice ages, Paleoceanography, 21, PA2005, doi:10.1029/2005PA001154, 2006.

Tomczak, M. and Godfrey, J. S: Regional Oceanography: An Introduction, Second Edition, 390 pp., 2003.

Trenberth, K. E. and Caron, J. M.: Estimates of meridional atmosphere and ocean heat transports, J. Clim., 14, 3433-3443, 2001.

Tzedakis, P. C., Raynaud, D., McManus, J. F., Berger, A., Brovkin, V., and Kiefer T.: Interglacial diversity, Nature Geosci., 2, 751755, 2009.

Tziperman, E. and Gildor, H.: On the mid-Pleistocene transition to 100-kyr glacial cycles and the asymmetry between glaciation and deglaciation times, Paleoceanography, 18, 2003.

Vidal, L., Schneider, R. R., Marchal, O., Bickert, T., Stocker, T. F., and Wefer, G.: Link between the North and South Atlantic during the Heinrich events of the last glacial period, Clim. Dynam., 15, 909-919, 1999.

Waelbroeck, C., Labeyrie, L., Michel, E., Duplessy, J. C., McManus, J. F., Lambeck, K., Balbon, E., and Labracherie, M.: Sea-level and deep water temperature changes derived from benthic foraminifera isotopic records, Quaternary Sci. Rev., 21, 295305, 2002.

Waelbroeck, C., Mulitza, S., Spero, H., Dokken, T., Kiefer, T., 
and Cortijo, E.: A global compilation of late Holocene planktonic foraminiferal delta O-18: relationship between surface water temperature and delta O-18, Quaternary Sci. Rev., 24, 853$868,2005$.

Wan, X., Chang, P, and Schmidt, M. W.: Causes of tropical Atlantic paleo-salinity variation during periods of reduced AMOC, Geophys. Res. Lett., 37, L04603, doi:10.1029/2009GL042013, 2010 .

Wang, C. Z. and Lee, S. K.: Atlantic warm pool, Caribbean lowlevel jet, and their potential impact on Atlantic hurricanes, Geophys. Res. Lett., 34, L02703, doi:10.1029/2006GL028579, 2007.

Watanabe, T., Winter, A., and Oba, T.: Seasonal changes in sea surface temperature and salinity during the Little Ice Age in the Caribbean Sea deduced from $\mathrm{Mg} / \mathrm{Ca}$ and $\mathrm{O}-18 / \mathrm{O}-16$ ratios in corals, Mar. Geol., 173, 21-35, 2001.

Weldeab, S., Schneider, R. R., and Kolling, M.: Deglacial sea surface temperature and salinity increase in the western Tropical Atlantic in synchrony with high latitude climate instabilities, Earth Planet. Sc. Lett., 241, 699-706, 2006.
Wolff, T., Mulitza, S., Arz, H., Patzold, J., and Wefer, G.: Oxygen isotopes versus CLIMAP (18 ka) temperatures: A comparison from the Tropical Atlantic, Geology, 26, 675-678, 1998.

Wüst, G.: Stratification and Circulation in the Antillean-Caribbean Basins, Columbia University Press, New York, 1964.

Yin, Q. Z., and Berger A.: Insolation and $\mathrm{CO}_{2}$ contribution to the interglacial climate before and after the Mid-Brunhes Event, Nature Geosci., 3, 243-246, 2010.

Zaucker, F. and Broecker, W. S.: The influence of atmospheric moisture transport on the fresh water balance of the Atlantic drainage basin: General circulation model simulations and observations, J. Geophys. Res., 97, 2765-2773, 1992.

Ziegler, M., Nurnberg, D., Karas, C., Tiedemann, R., and Lourens, L. J.: Persistent summer expansion of the Atlantic Warm Pool during glacial abrupt cold events, Nature Geosci., 1, 601-605, 2008 . 